PROGRAMA INTERUNIDADES DE PÓS-GRADUAÇÃO EM BIOINFORMÁTICA UNIVERSIDADE DE SÃO PAULO

TESE DE DOUTORADO

\title{
UMA ABORDAGEM INTEGRATIVA USANDO DADOS DE INTERAÇÃO PROTEÍNA-PROTEÍNA E ESTUDOS GENÉTICOS PARA PRIORIZAR GENES E FUNÇÕES BIOLÓGICAS EM TRANSTORNO DE DÉFICIT DE ATENÇÃO E HIPERATIVIDADE
}

LEANDRO DE ARAÚJO LIMA

(llima@ime.usp.br)

\section{ORIENTADORA: HELENA BRENTANI}

CO-ORIENTADOR: RONALDO FUMIO HASHIMOTO

Durante o desenvolvimento deste trabalho o autor recebeu auxílio financeiro da CAPES (Coordenação de Aperfeiçoamento de Pessoal de Nível Superior)

São Paulo, 22 de julho de 2015 


\section{UMA ABORDAGEM INTEGRATIVA USANDO DADOS DE INTERAÇÃO PROTEÍNA-PROTEÍNA E ESTUDOS GENÉTICOS PARA PRIORIZAR GENES E FUNÇÕES BIOLÓGICAS EM TRANSTORNO DE DÉFICIT DE ATENÇÃO E HIPERATIVIDADE}

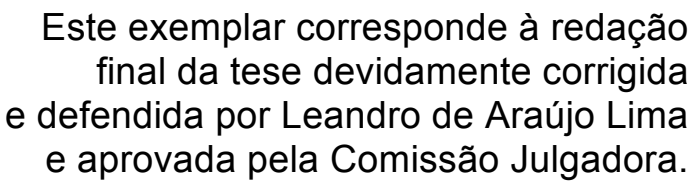

Banca examinadora:

- Profa. Helena Brentani (orientadora) - FM-USP

- Prof. André Fujita - IME-USP

- Prof. Roberto Marcondes Cesar Jr - IME-USP

- Profa. Suely Kazue Nagahashi Marie - FM-USP

- Prof. Guilherme Vanoni Polanczyk - FM-USP 


\section{Agradecimentos}

A Deus, pelo dom da vida e por ter me dado um cérebro com o potencial de estudar assuntos tão legais.

A minha esposa, Priscila, pela abdicação, paciência e apoio durante esses 4 longos anos. Seu amor e dedicação sempre foram muito importantes para o meu sucesso.

À minha família e à família da minha esposa, pelo apoio e por sempre estarem presentes nos momentos mais difíceis. Em especial à minha mãe, por nos momentos finais dessa luta ter ficado ao meu lado e pela super ajuda no dia da defesa.

Aos amigos do CAJU, pela amizade. Principalmente aos amigos Rodolfo, Sarah, Erika e René, nos últimos momentos do doutorado. À tia Maria e Wilson, pela força na semana da defesa.

Aos muitos amigos da IASD Brasileira de Philadelphia, pela amizade e auxílio durante o final, etapa crucial do meu doutorado.

Aos colegas e colaboradores do Children's Hospital of Philadelphia (CHOP), onde fui muito bem recebido do início ao fim do meu estágio de um ano e meio. Agradeço principalmente ao Dr. Hakon Hakonarson por ter me recebido e me co-orientado nesse tempo. Também agradeço ao Dr. Patrick Sleiman, pelos conselhos fundamentais para a conclusão do meu trabalho. Agradeço também à amiga Renata Pellegrino, sua mãe e seu esposo, por terem nos recebido de forma tão acolhedora, nos nossos primeiros dias na Philadelphia.

Agradeço também à Edukar, pelo apoio financeiro e planejamento de carreira durante os últimos anos do doutorado. À CAPES, também pelo financiamento.

Ao Dr. Emmanuel Dias-Neto, do Hospital A.C. Camargo, pelo apoio durante o início do doutorado.

Aos colegas David Correa Martins Jr, Sérgio Nery e Guilherme Mota, pela colaboração científica. Também agradeço aos colegas Cecília Feio, Ana Tahira, Viviane Neri, Daniel Mariani e Renato Puga, pelo auxílio com as análises do trabalho.

Aos membros da banca, por terem aceitado ler a tese e fazer parte do comitê.

Ao meu co-orientador, Ronaldo Hashimoto, pelas reuniões e sugestões em relação à metodologia do meu trabalho.

Para encerrar, eu agradeço muito à minha orientadora, Dra. Helena Brentani, pelo aprendizado, confiança e colaboração em diversos trabalhos. Nesse período em que temos trabalhado juntos, tive a oportunidade de aprender bastante e ter contato com pesquisadores renomados em minha área de estudo.

Sem essas pessoas citadas acima, teria sido impossível concluir esse trabalho. 


\section{Conteúdo}

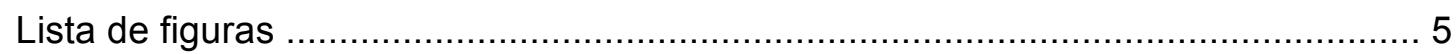

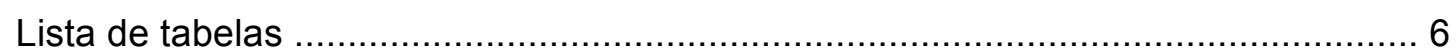

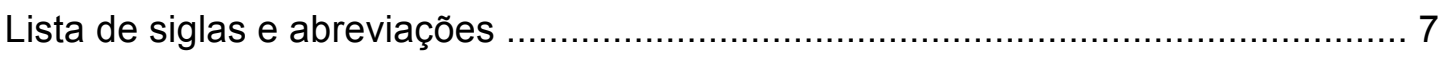

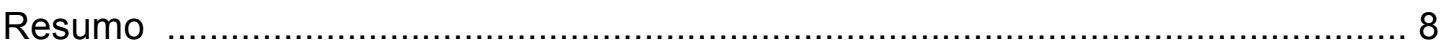

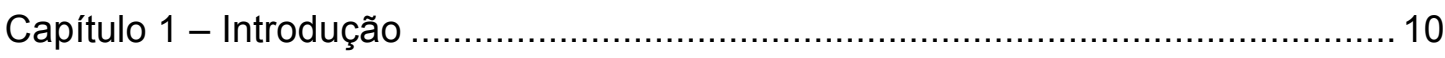

Capítulo 2 - Genética de doenças complexas ..................................................... 13

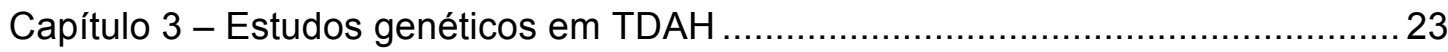

Capítulo 4 - Integração de dados biológicos …..................................................2 27

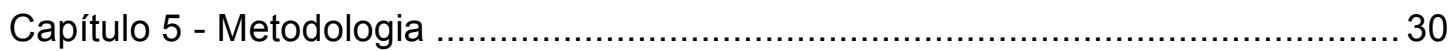

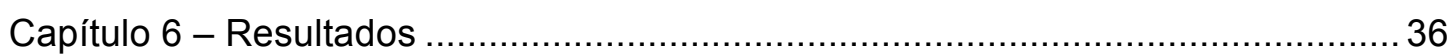

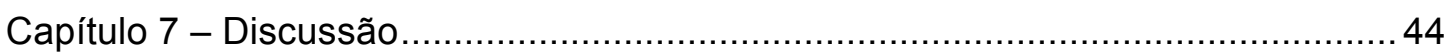

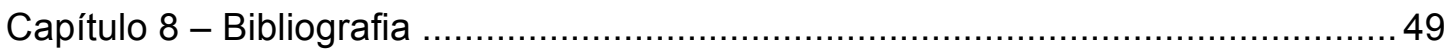




\section{Lista de figuras}

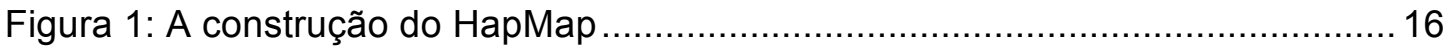

Figura 2. Visão geral das análises realizadas nesse trabalho ............................... 30

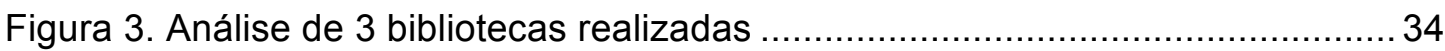

Figura 4. Gráfico de barras com as percent. de variantes herdadas e de novo........ 39

Figura 5. Rede criada com os genes utilizados nas análises deste trabalho ............40 40

Figura 6. Rede com genes em pelo menos 2 ocorrências nas análises .................. 43

As figuras deste texto e outras suplementares se encontram disponíveis no seguinte website:

http://www.ime.usp.br/ /lima/doutorado/ 


\section{Lista de tabelas}

Tabela 1: Método competitivo sem evidência de enriquecimento ............................ 19

Tabela 2: Método competitivo com evidência de enriquecimento............................. 19

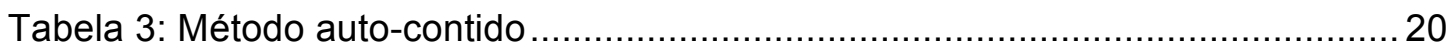

Tabela 4: Alguns bancos de dados de vias metabólicas e funções biológicas .......... 20

Tabela 5. As 26 variantes de único nucleotídeo de novo dos trios brasileiros ...........37

Tabela 6. Genes com pelo menos duas ocorrências em categorias diferentes ........ 40

Tabela 7. Termos de KEGG dos genes na sub-rede ...........................................43

Todas as tabelas suplementares estão disponíveis no final do texto e no seguinte website:

http://www.ime.usp.br/ llima/doutorado/ 


\section{Lista de siglas e abreviações}

CNV: copy number variation (Variação do Número de Cópias)

DL: desequilíbrio de ligação

EM: esclerose múltipla

GSA: gene-set analysis (análise de conjuntos de genes)

GO: Gene Ontology (banco de dados de ontologias relacionadas a genes)

GWAS: genome-wide association study (estudo de associação ao longo do genoma)

KEGG: Kyoto Encyclopedia of Genes and Genomes (banco de dados de vias metabólicas)

MAF: minor allele frequency (frequência do menor alelo)

PPI: protein-protein interaction (interação proteína- proteína)

SNP: single nucleotide polymorphism (polimofismo de único nucleotídeo)

SNV: single nucleotide variant (variação de único nucleotídeo - não

necessariamente são comuns, como os SNPs)

TDAH: transtorno de déficit de atenção com hiperatividade

TDT: transmission disequilibrium test (teste de transmissão de desequilíbrio) 


\section{Resumo}

O Transtorno de Déficit de Atenção e Hiperatividade (TDAH) é a doença do neurodesenvolvimento mais comum na infância, afetando cerca de 5,8\% de crianças e adolescentes no mundo. Muitos estudos vêm tentando investigar a suscetibilidade genética em TDAH, mas sem muito sucesso. Este estudo teve como objetivo analisar variantes raras e comuns contribuindo para a arquitetura genética do TDAH. Foram gerados os primeiros dados de exoma de TDAH de 30 trios brasileiros em que o filho foi diagnosticado com TDAH esporádico. Foram analisados tanto variações de único nucleotídeo (ou SNVs, single-nucleotide variants) quanto variações de número de cópias (ou CNVs, copy-number variants), tanto nesses trios quanto em outros conjuntos de dados, incluindo uma amostra brasileira de 503 crianças/adolescentes controles, bem como resultados previamente publicados em quatro estudos com variação de número de cópias e uma meta-análise de estudos de associação ao longo do genoma. Tanto os trios quanto os controles fazem parte da Coorte de Escolares de Alto Risco para o desenvolvimento de Psicopatologia e Resiliência na Infância do Instituto Nacional de Psiquiatria do Desenvolvimento (INPD). Os resultados de trios brasileiros mostraram três padrões marcantes: casos com variações herdadas e somente SNVs de novo ou CNVs de novo, e casos somente com variações herdadas. Embora o tamanho amostral seja pequeno, pudemos ver que diferentes comorbidades são mais frequentes em casos somente com variações herdadas. Após explorarmos a composição de variações nos probandos brasileiros, foram selecionados genes recorrentes entre amostras do nosso estudo ou em bancos de dados públicos. Além disso, usando somente genes expressos no cérebro (amostras pós-mortem dos projetos Brain Atlas e GenotypeTissue Expression), construímos uma rede de interação proteína-proteína "in silico" com interações físicas confirmadas por pelo menos duas fontes. Análises topológicas e funcionais dos genes da rede mostraram genes relacionados a sinapse, adesão celular, vias glutamatérgicas e serotonérgicas, o que confirma achados de trabalhos independentes na literatura indicando ainda novos genes e variantes genéticas nessas vias. 


\section{Abstract}

Attention-Deficit/Hyperactivity Disorder (ADHD) is the most common neurodevelopmental disorder in children, affecting $5.8 \%$ of children and adolescents in the world. Many studies have attempted to investigate the genetic susceptibility of ADHD without much success. The present study aimed to analyze rare and common variants contributing to the genetic architecture of ADHD. We generated exome data from 30 Brazilian trios where the children were diagnosed with sporadic ADHD. We analyzed both single-nucleotide variants (SNVs) and copy-number variants (CNVs) in these trios and across multiple datasets, including a Brazilian sample of 503 children/adolescent controls from the High Risk Cohort Study for the Development of Childhood Psychiatric Disorders, and also previously published results of four CNV studies of ADHD involving children/adolescent Caucasian samples. The results from the Brazilian trios showed 3 major patterns: cases with inherited variations and de novo SNVs or de novo CNVs and cases with only inherited variations. Although the sample size is small, we could see that various comorbidities are more frequent in cases with only inherited variants. After exploring the rare variant composition in our 30 cases we selected genes with variations (SNVs or located in CNV regions) in our trio analysis that are recurrent in the families analyzed or in public data sets. Moreover, using only genes expressed in brain (post-mortem samples from Brain Atlas and The Genotype-Tissue Expression project), we constructed an "in silico" protein-protein interaction (PPI) network, with physical interactions confirmed by at least two sources. Topological and functional analyses of genes in this network uncovered genes related to synapse, cell adhesion, glutamatergic and serotoninergic pathways, both confirming findings of previous studies and capturing new genes and genetic variants in these pathways. 


\section{Capítulo 1 - Introdução}

$\mathrm{Na}$ última década, muitos estudos têm sido publicados tentando investigar a suscetibilidade genética para o transtorno de déficit de atenção e hiperatividade - o TDAH (Smalley, Kustanovich et al. 2002, Ogdie, Fisher et al. 2004, Lasky-Su, Anney et al. 2008, Lesch, Timmesfeld et al. 2008, Banaschewski, Becker et al. 2010, Neale, Medland et al. 2010, Williams, Zaharieva et al. 2010, Lesch, Selch et al. 2011, Lionel, Crosbie et al. 2011, Elia, Glessner et al. 2012). Este transtorno é o mais comum dentre os transtornos psiquiátricos da infância, afetando cerca de $5,8 \%$ de crianças e adolescentes no mundo todo (Polanczyk and Rohde 2007). Estudos de associação ao longo do genoma (ou GWAS, do inglês genome-wide association studies) têm sido utilizados para buscar variantes de efeito pequeno a médio (Lesch, Timmesfeld et al. 2008, Neale, Lasky-Su et al. 2008, Lantieri, Glessner et al. 2010). A carência de replicação têm sido uma constante na área. Esta falta de resultados positivos, no entanto, não é uma surpresa. Apesar da abordagem promissora, genes identificados por GWAS contribuem apenas com uma uma porcentagem pequena da herdabilidade de traços complexos (Frazer, Murray et al. 2009) tendo baixa replicação entre estudos (Mitchell and Porteous 2011). Este fenômeno parece ser devido à combinação do efeito modesto de mutações causais na suscetibilidade à doença e ao baixo poder de estudos com uma quantidade insuficiente de amostras. Como uma alternativa, existem as meta-análises, que unem amostras de vários estudos. Em TDAH, no entanto, mesmo esse tipo de análise não obteve sucesso em descobrir polimorfismos de único nucleotídeo (ou SNPs, do inglês single-nucleotide polymorphisms) com associação significante (Neale, Medland et al. 2010). Como uma alternativa à hipótese da "doença comum-variação comum", as variações de número de cópias (ou CNVs, do inglês copy-number variation) têm sido analisadas em doenças psiquiátricas para a busca de candidatos para a hipótese da "doença comum-variação rara" e isso têm gerado resultados bem sucedidos (Sebat, Lakshmi et al. 2007, Girirajan, Brkanac et al. 2011). Diferentes estudos que investigaram CNVs têm contribuído para a literatura da genética em TDAH (Williams, Zaharieva et al. 2010, Lesch, Selch et al. 2011, Lionel, Crosbie et al. 2011, Elia, Glessner et al. 2012, Stergiakouli, Hamshere et al. 2012, Yang, Neale et al. 2013) e em um artigo recente foi mostrado que CNVs em TDAH são hiperrepresentados por genes ohnólogos como também em outras doenças do neurodesenvolvimento (McLysaght, Makino et al. 2014).

Uma vasta literatura também têm surgido mostrando algoritmos de integração de diferentes bancos de dados para priorizar variações importantes e assim entender doenças complexas, inclusive transtornos psiquiátricos (Baranzini, Galwey et al. 2009, Akula, Baranova et al. 2011, Poelmans, Pauls et al. 2011, Rossin, Lage et al. 2011, Jia and Zhao 2012, Lee, Raygada et al. 2012). Usando achados prévios em TDAH na literatura, Chang e colaboradores (2012) construíram um banco de dados (ADHDgene, disponível em http://adhd.psych.ac.cn/). O grupo também publicou uma lista importante de genes baseada na interseção de cinco ferramentas de priorização de genes. Poelmans (2011) e colegas usaram os 
resultados de cinco estudos de associação ao longo do genoma em TDAH previamente publicados para buscar por vias e funções biológicas. Eles realizaram uma busca sistemática na literatura por funções (putativas) de proteínas codificadas pelos 85 melhores genes desses GWAS.

Numa abordagem complementar, novas aplicações promissoras de redes de proteínas em doenças têm sido descritas com quatro objetivos principais: identificar novos genes de doenças, estudar suas propriedades na rede, identificar sub-redes relacionadas a doenças e classificação de doenças baseada em redes (Ideker and Sharan 2008, Sun 2012). A base lógica para o uso de integração de dados baseado em interações proteína-proteína (ou PPI, do inglês protein-protein interaction) está na hipótese da localidade na rede (Barabasi, Gulbahce et al. 2011). De acordo com essa hipótese, proteínas relacionadas às mesmas doenças ou fenótipos tendem a interagir ou estar próximas na rede (ver também (Zhao, Yang et al. 2011). Abordagens usando dados de GWAS e redes PPI já foram publicados com doenças psiquiátricas, como transtorno bipolar (Akula, Baranova et al. 2011), esquizofrenia (Jia and Zhao 2012), autismo (Lee, Raygada et al. 2012), bem como em TDAH (Elia, Glessner et al. 2012). Elia e colaboradores (2012) usaram redes PPI para investigar genes hiperrepresentados em CNVs que afetavam múltiplas coortes. Eles relataram que os genes que interagiam com os genes da família de receptores de glutamato estavam enriquecidos em aproximadamente $10 \%$ dos casos, mostrando a associação dos genes receptores de glutamato com TDAH.

Com o desenvolvimento de novas técnicas para investigar alterações no DNA, foi possível descobrir causas para uma quantidade maior de condições e fenótipos. Para algumas doenças complexas, foi necessário aplicar métodos para analisar variantes ao longo do genoma com placas ("arrays") de SNPs, e também usar sequenciamento para encontrar e combinar variações comuns e raras (Hamshere, Langley et al. 2013, Lee, Ripke et al. 2013, Kavanagh, Tansey et al. 2014). Dados de sequenciamento de larga escala tornaram possível cobrir regiões genômicas com mutações de baixa frequência na população, mas que também podem ter impacto em doenças complexas (Yang, Neale et al. 2013, Kavanagh, Tansey et al. 2014). Além disso, diferentes tipos de variantes muito raras, como as de novo e até mesmo variações herdadas com impacto na codificação da proteína podem contribuir para o surgimento de doenças do neurodesenvolvimento $(\mathrm{He}$, Sanders et al. 2013, Escudero and Johnstone 2014).

Em outras doenças psiquiátricas complexas, como autismo (Wang, Zhang et al. 2009, State and Levitt 2011, Devlin and Scherer 2012) e esquizofrenia (Rodriguez-Murillo, Gogos et al. 2012, Schizophrenia Working Group of the Psychiatric Genomics Consortium 2014), o papel de variantes comuns e raras já têm sido mostrado, bem como o de CNVs menores (Krumm, O'Roak et al. 2013, Poultney, Goldberg et al. 2013). Esses estudos mostram que a arquitetura genética de doenças psiquiátricas do neurodesenvolvimento pode ser composta da combinação de diferentes tipos de variantes. Como proposto por Girirajan e Eichler (2010), nós usamos no presente trabalho tanto variações de novo quanto herdadas para integrar nosso modelo da arquitetura genética de TDAH, usando uma análise de exoma de 30 trios brasileiros, cuja criança tem TDAH esporádico, variações de 
trabalhos já publicados por outros grupos em genética de TDAH e bancos de interação proteína-proteína.

A seguir, os próximos capítulos apresentarão as estratégias utilizadas para entendermos melhor a arquitetura genética do TDAH. No Capítulo 2 - Genética de doenças complexas, será mostrada a diferença da genética de doenças monogênicas e doenças complexas, bem como algumas técnicas para encontrar genes candidatos nesse tipo de doença. No Capítulo 3 - Estudos genéticos em TDAH, serão revisados os principais e mais recentes estudos sobre as causas genéticas do transtorno de déficit de atenção e hiperatividade. No Capítulo 4 - Integração de dados biológicos, serão mostrados alguns métodos de para a utilização de informações de diferentes contextos, técnicas e plataforma em análises de Bioinformática, bem como vantagens e limitações. No Capítulo 5 -- Metodologia, serão mostradas as análises feitas com bancos de dados públicos de variações genéticas em TDAH, bem como as análises realizadas a partir dos dados de exoma de trios brasileiros com pais saudáveis e crianças que têm a doença. No Capítulo 6 - Resultados, serão mostrados os principais achados quando estudamos as variações nos trios separadamente e quando juntamos a essas as variantes provenientes de dados públicos. No Capítulo 7 - Discussão, serão abordadas as funções biológicas encontradas, bem como genes separadamente e as comparações entre famílias em que foram encontradas somente variações herdadas com famílias em que foram encontradas variações de novo. Para encerrar o texto da tese, serão apresentadas a Bibliografia e a experiência adquirida ao longo desse trabalho de doutorado, bem como as referências dos artigos aceitos em revistas ou conferências em que o aluno participou durante esse período. 


\section{Capítulo 2 - Genética de doenças}

\section{complexas}

\section{1 - Doenças Monogênicas x Doenças Complexas}

Até pouco tempo atrás, era senso comum que várias doenças poderiam ser causadas pela ação de um único gene (Bush and Moore 2012). Um estudo de sucesso para identificação dessas alterações ocorreu em fibrose cística (Kerem, Rommens et al. 1989). A análise de marcadores genéticos ao longo do genoma em famílias portadoras da doença permitiu encontrar várias mutações no gene CFTR, sendo consequentemente apontadas como causadoras da doença. Essas doenças são também chamadas de doenças monogênicas ou doenças Mendelianas, pois seguem exatamente o que chamamos de princípios da herdabilidade de Mendel, ou herança Mendeliana. Isso se deve ao fato de Gregor Johann Mendel, um monge austríaco do séc. XIX, ter sido o primeiro a conceber a ideia de unidades hereditárias, que chamou inicialmente de fatores, mas mais tarde foram chamados genes. Fazendo experimentos com diferentes tipos de ervilhas, Mendel percebeu que características como cor ou rugosidade, chamadas fenótipos, seguiam proporções bem definidas. A partir disso, o monge afirmou que cada indivíduo tem dois fatores para cada característica (ou traço), um de cada pai (ou antecessor direto). A classificação de doença Mendeliana é dada a uma doença que é causada por um único locus.

Para tais doenças, a mutação em um único gene já pode causar o distúrbio, que é herdado seguindo exatamente as leis estabelecidas por Gregor Mendel. A ideia de doenças monogênicas se opõe ao conceito de doenças poligênicas, ou multifatoriais, que podem ser causadas por alterações em vários genes, e ainda pela ação do ambiente. Argumentos de que a herança de uma doença é poligênica vêm da observação de que, apesar de a doença ser encontrada em membros da mesma família, elas não tendem a seguir o modelo de herança Mendeliana (Mitchell 2012). Temos que ter em mente que algumas características podem ser encontradas na mesma família porque, além de passar os genes para os filhos, os pais também fornecem a eles o mesmo ambiente (por exemplo: o mesmo local de moradia, a mesma alimentação, ou o mesmo tipo de tratamento médico).

Para calcular a contribuição do ambiente e a contribuição genética para um determinado traço ou doença, uma das alternativas usadas por geneticistas é o estudo com gêmeos monozigóticos (MZ). Dada a variação fenotípica para determinado traço, para saber a contribuição do ambiente, por exemplo, teríamos que minimizar a variação genética; e para saber a contribuição genética, teríamos que minimizar a variação das condições do ambiente. Imagine o seguinte exemplo fictício: num determinado planeta, a variação na altura dos homens adultos é $50 \mathrm{~cm}$. Para saber a contribuição ambiental para a variação da altura, teríamos que colocar vários homens com a mesma composição genética (vários clones) deixando variar somente os tipos de ambiente. Ao medir a variação da altura de homens adultos nesse planeta, encontraríamos a contribuição do ambiente neste traço. Caso a variação fosse $20 \mathrm{~cm}$, por exemplo, poderíamos afirmar que a contribuição da 
variação genotípica nesse traço seria de $30 \mathrm{~cm}$. Assim, a herdabilidade para a altura seria de $100 \times 30 \mathrm{~cm} / 50 \mathrm{~cm}=60 \%$. Outra maneira de calcular a herdabilidade seria medir a altura de vários homens adultos em um planeta em que o ambiente fosse uniforme em todos os lugares. Assim, essa variação de altura (que seria de $30 \mathrm{~cm}$ ) sofreria influência só da variação genotípica nesses homens, e a herdabilidade também seria calculada como $60 \%$.

Em estudos com gêmeos monozigóticos (que são seres que compartilham o mesmo material genético ao nascerem) tenta-se simular o planeta dos clones, em que só o ambiente varia. Se dois irmãos gêmeos monozigóticos compartilham as mesmas características com mais frequência quando comparados a gêmeos dizigóticos (DZ) ou qualquer par de irmãos, isso pode indicar que o traço tem grande contribuição genética (ou seja, recebe influência da variação genotípica). A isso damos o nome de concordância. Por exemplo, se fossem testados 100 pares de gêmeos em que pelo menos um dos irmãos tem Transtorno de Déficit de Atenção e Hiperatividade (TDAH), e fosse constatado que em 60 pares o outro irmão também tem TDAH, a concordância seria de $60 \%$. A fórmula para calcular a herdabilidade nesse tipo de estudo é:

$$
h^{2}=\left(C_{m z}-C_{d z}\right) /\left(1-C_{d z}\right),
$$

em que $\mathbf{h}^{2}$ é a herdabilidade (que mede a fração da variação em razão dos genes); $\mathbf{C}_{\mathrm{mz}}$ é a taxa de concordância entre co-gêmeos $\mathbf{M Z}$ e $\mathbf{C}_{\mathrm{dz}}$ entre co-gêmeos $\mathbf{D Z}$ (Otto et al., 2004). Em um estudo em esquizofrenia, por exemplo, foram encontradas concordâncias de $58 \%$ e $13 \%$ para gêmeos $M Z$ e DZ, respectivamente. Logo, a herdabilidade $h^{2}$ para esquizofrenia neste estudo é de $(0,58-0,13) /(1-0,13)=$ 0,52 (aproximadamente), indicando que a esquizofrenia tem cerca de metade da sua variação fenotípica dependendo do ambiente e metade dependendo da variação genotípica.

Caso fosse possível separar gêmeos monozigóticos ao nascerem, e criados em famílias (ambientes) diferentes, seria ainda melhor para verificar a influência do ambiente em determinado traço. Como essa separação forçada é impraticável, podem ser feitos estudos com irmãos que já foram adotados (criados) por famílias diferentes. Dois exemplos de estudos que poderiam ser feitos são: encontrar pessoas adotadas que sofrem de uma doença já conhecida como ocorrendo com mais frequência na mesma família e ver se essa doença está presente na família original (indicando influência genotípica) ou na família adotiva (indicando influência do ambiente); ou ainda encontrar famílias em que os pais (o pai ou a mãe, pelo menos) sejam afetados por uma doença e que algum filho tenha sido adotado por outra família, e verificar se o filho desenvolveu a doença (indicando influência genotípica) ou se ele não desenvolveu (indicando influência do ambiente). Em diferentes estudos com gêmeos, tem-se calculado valores de herdabilidade em TDAH variando entre 70 e $80 \%$ (Faraone, Perlis et al. 2005, Lesch, Timmesfeld et al. 2008, Banaschewski, Becker et al. 2010), podendo esta ser considerada uma das doenças psiquiátricas com maior herdabilidade.

\section{2 - O estudo das doenças complexas (ou doenças de herança complexa)}


Estudos de ligação foram utilizados com sucesso para analisar doenças Mendelianas, como a fibrose cística e a doença de Huntington (Bush and Moore, 2012). No entanto, quando usados em doenças complexas, geralmente mais comuns, como doença cardíaca ou alguns tipos de câncer, os estudos de ligação não alcançaram o sucesso desejado, implicando que os mecanismos genéticos em doenças Mendelianas podem ser diferentes dos mecanismos em doenças complexas (Hirschhorn and Daly 2005). O sucesso limitado dos estudos de ligação em doenças complexas tem sido atribuído ao seu baixo poder e resolução para capturar variações de efeito modesto (Manolio, Collins et al. 2009).

Em 2001, Reich e Lander postularam a hipótese da doença comum/variação comum (DC/VC), sugerindo que em doenças comuns as variações responsáveis deveriam ser também mais comuns na população. Não há na verdade um consenso de limiar para determinar o que seria uma doença comum ou doença rara. Em geral, esses critérios dependem da localidade (a porcentagem da população afetada para que uma doença seja considerada rara pode ser diferente nos Estados Unidos, no Japão e na Europa, por exemplo). Em geral, pode-se assumir o limiar como em torno de $1 \%$ da população para decidir se uma doença é rara ou comum. No entanto, essa hipótese, que dominou a área da genética nos últimos anos, tem-se enfraquecido pelo fato de os estudos genéticos explicarem em geral só uma parte pequena da variação genética. Essa hipótese tem sido testada em muitas doenças comuns nos últimos anos. Embora a maioria da herdabilidade nessas doenças ainda se mantenha inexplicada, tem-se comprovado que alelos comuns desempenham um papel importante na suscetibilidade (Bush and Moore 2012).

Após o mapeamento do genoma humano (Lander, Linton et al. 2001, Venter, Adams et al. 2001, Abecasis, Altshuler et al. 2010), muitos dados genéticos têm sido coletados no intuito de encontrar alterações que possam estar relacionadas a doenças. Com o aperfeiçoamento de técnicas de genotipagem e sequenciamento, essas alterações, principalmente polimorfismos de único nucleotídeo (ou SNPs, do inglês single nucleotide polymorphisms), têm sido encontradas e guardadas de maneira massiva em bancos de dados públicos (International HapMap 3 Consortium, Altshuler et al. 2010, Abecasis, Auton et al. 2012). Com estes dados disponíveis, tem sido possível mapear as regiões em que há variações em diversas populações. Essas variações ficam disponíveis em bancos de dados públicos, como o dbSNP (Sherry, Ward et al. 2001). Estudos como o 1000 genomas (Abecasis, Auton et al. 2012) e o HapMap (International HapMap 3 Consortium, Altshuler et al. 2010) tiveram o objetivo de encontrar variantes presentes em diferentes populações (ex: européia, asiática e africana). O objetivo do Projeto 1000 genomas é encontrar as principais variações genéticas que tem frequência de pelo menos $1 \%$ nas populações estudadas. Tendo sequenciado mais de 1000 pessoas com uma cobertura de até $50 x$ em regiões gênicas (ver mais detalhes em http://www.1000genomes.org). O HapMap é um catálogo de variantes genéticas comuns que ocorrem em seres humanos. Da mesma forma que no Projeto 1000 genomas, o HapMap descreve o que são essas variações, onde elas ocorrem em nosso DNA, e como elas estão distribuídas em pessoas de uma mesma população e entre populações de diferentes partes do mundo (ver mais detalhes em http://hapmap.org/whatishapmap.html). Nesses projetos, foram identificados 
aproximadamente 10 milhões de SNPs, número que é bem menor que o tamanho aproximado de todo o genoma (cerca de 6 bilhões de nucleotídeos). Ainda assim, essa quantidade ainda é muito grande, e testar todas as variações nas pessoas seria muito custoso.

Variantes genéticas (SNPs, por exemplo) próximas tendem a ser herdadas juntas, e isso significa que algumas partes do DNA se mantêm iguais. Dessa forma, todas as pessoas que possuem uma determinada variação em uma posição tendem a ter as mesmas variações em posições próximas. Combinações dessas variações são chamadas de haplótipos, e é possível também encontrar SNPs que os identificam de forma única. Esses SNPs são chamados de "tag" (etiqueta, em inglês) SNPs, por funcionarem como uma espécie de identificador do haplótipo. Ao identificar os tag-SNPs de uma pessoa, é possível saber como estão os outros SNPs dessa pessoa. Assim, para cada pessoa, bastaria testar os tag-SNPs, estimados em cerca de 300.000 a 600.000 , que é uma quantidade bem menor que todos os 10 milhões de SNPs comuns.

a) SNPs
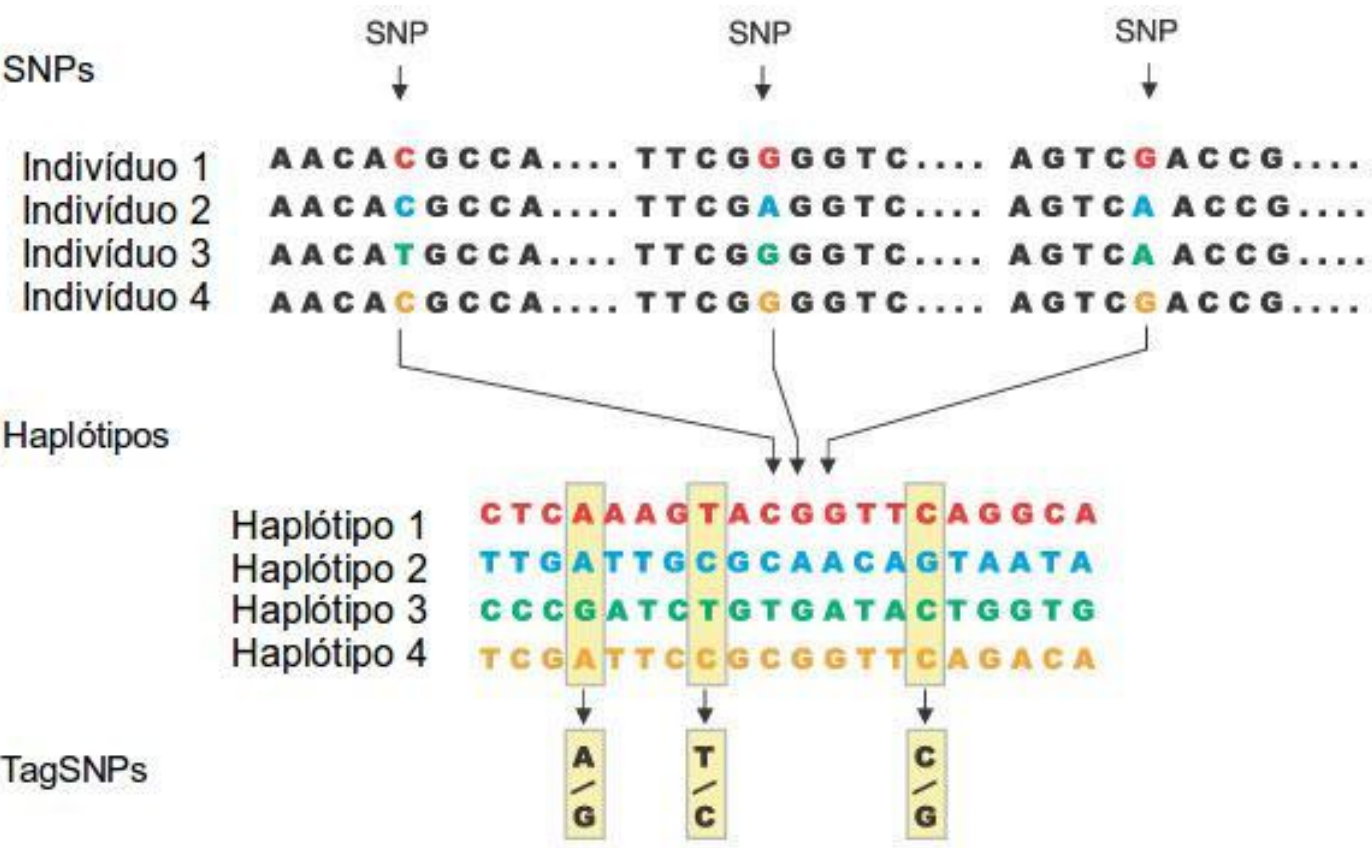

Figura 1: A construção do HapMap (adaptada do site http://hapmap.org/whatishapmap.html). a) Os SNPs são identificados nas amostras de vários indivíduos. b) SNPs próximos que são herdados juntos são unidos em haplótipos. c) São identificados tagSNPs dentro dos haplótipos para identificá-los de forma única.

\section{3 - Busca de genes candidatos para doenças complexas: Estudos de associação ao longo do genoma}

Estudos de associação ao longo do genoma (ou GWAS, do inglês genome-wide association studies) são livres de hipótese, verificando SNPs em todos os genes e regiões regulatórias do genoma e têm o potencial de descobrir novos genes ou alterações de risco. É importante ressaltar que estes estudos usam uma amostra de variações que são representantes de regiões ao longo do genoma, com base nos 
blocos de baixa recombinação ou desequilíbrio de ligação (DL). Se um SNP aparece com uma associação com uma doença, não necessariamente isso quer dizer que o SNP está envolvido, pois a associação pode ser com um SNP que está em DL com o que foi usado no estudo. Logo, o objetivo desses estudos não é necessariamente identificar os alelos causais de uma doença, mas apontar regiões que possam abrigar tais alterações.

Estes estudos partem do princípio de que uma doença comum é causada por alterações comuns, MAF (do inglês minor allele frequency) $>5 \%$. No GWAS, pesquisadores buscam diferenças estatisticamente significativas na frequência de variantes genéticas comuns entre os casos e controles em centenas de milhares de loci no genoma (Golub 2010, Liu, Zhang et al. 2013), utilizando um elevado número amostral.

Com estudos de associação pela extensão do genoma foram obtidos resultados positivos em várias doenças complexas. Foi possível encontrar várias regiões (loci) candidatas para diabetes tipo 1 e 2, doença de Crohn, esquizofrenia, distúrbio bipolar, esclerose múltipla e muitas outras (Mitchell 2012). Alguns desses resultados reforçaram estudos anteriores e outros apontaram novas descobertas, implicando novos genes nos processos das doenças. Também é interessante notar que em algumas doenças esses resultados convergem para processos bioquímicos e vias metabólicas específicas, como disfunção de células beta ou ação de insulina em diabetes do tipo 2 (Voight, Scott et al. 2010, Imamura and Maeda 2011), sinalização de peptídeo natriurético em pressão sanguínea elevada e risco de doença cardiovascular (Ehret, Munroe et al. 2011), genes do sistema imune em esclerose múltipla (Sawcer, Hellenthal et al. 2011), imunidade inata e inflamação em doença de Crohn (Mathew 2008), e desenvolvimento neural em esquizofrenia (Purcell, Wray et al. 2009, Schizophrenia Psychiatric Genome-Wide Association Study (GWAS) Consortium 2011). Estes estudos também mostraram riscos genéticos compartilhados entre diferentes doenças, como várias doenças autoimunes (diabete tipo 1, doença de Crohn, esclerose múltipla e outras) (Cotsapas, Voight et al. 2011) e entre esquizofrenia e distúrbio bipolar (Purcell, Wray et al. 2009, Psychiatric GWAS Consortium Bipolar Disorder Working Group 2011, Schizophrenia Psychiatric Genome-Wide Association Study (GWAS) Consortium 2011).

Apesar do sucesso do GWAS em vários distúrbios, ainda é bem difícil capturar variações que explicam toda a variação genética dessas doenças. As variações associadas estatisticamente significantes atuam na doença com um efeito muito pequeno. Isso corresponde exatamente a modelos de doenças poligênicas, em que não se espera que variantes individuais tenham grande efeito. Em muitos casos, SNPs que alcançam critério para significância a nível genômico podem explicar matematicamente somente uma porcentagem pequena da variação genética da doença, ainda que usados coletivamente. Ou seja, uma pessoa que tem algum dos SNPs associados tem um risco aumentado de ter a doença, mas pode haver outros SNPs que aumentem esse risco e que não foram descobertos ainda. Isso tem levado a crer que a hipótese doença comum/variação comum não é uma verdade absoluta (Mayo 2007), dado que doenças comuns podem ser explicadas por múltiplas variações raras (McClellan, Susser et al. 2007). 
Dessa forma, esses estudos de associação necessitam de um grande número de amostras para a identificação de variantes de risco da doença em questão. O cálculo amostral para a detecção de associações é conhecido por ser altamente afetado pela prevalência da doença, frequência alélica, desequilíbrio de ligação (DL), modelos de herança, e tamanho do efeito das variantes genéticas (como por exemplo, odds ratio, risco relativo, etc.) (Gordon, Levenstien et al. 2003, Pfeiffer and Gail 2003, Scherag, Muller et al. 2003). Entretanto, à medida que o tamanho da amostra aumenta e, por consequência, uma maior quantidade de dados é assimilada para análise combinada, o risco de associações espúrias devido à subestruturação populacional ou estratificação também aumenta (Devlin and Roeder 1999, Devlin, Roeder et al. 2001). Outra questão fundamental, que ocorre ao aumentarmos o número amostral e que pode contribuir para resultados com falsos positivos assim como com falsos negativos em GWAS é a variabilidade fenotípica que passa a existir dentro de grandes populações.

\section{4 - Alternativas para priorização gênica usando dados de GWAS: análises de conjuntos de genes}

Uma das maneiras de se diminuir a dimensionalidade dos dados é olhandose para genes (um mesmo gene pode representar vários SNPs) e/ou vias biológicas representadas (uma via é representada por vários genes). A análise de conjuntos de genes (ou GSA, do inglês Gene-set analysis) é uma das formas de, levando em conta um conjunto de genes envolvidos com um fenótipo, descobrir funções biológicas ou vias metabólicas relevantes que não ficariam evidentes analisando genes separadamente (Wang, Li et al. 2007, Fridley and Biernacka 2011). Tendo sido usada inicialmente em análise de dados de expressão gênica (microarray), o GSA (ou, nesse caso, GSEA, do inglês Gene-set Enrichment Analysis - análise de enriquecimento de conjuntos de genes) já foi usado para investigar várias doenças comuns, como câncer de mama, Alzheimer, esclerose múltipla e hipertensão, entre outras (Fridley and Biernacka 2011). Um exemplo recente de descoberta usando GSA foi que o gene PGE2 e genes da via de sinalização de cálcio estão envolvidos tanto com hipertensão quanto com doença de Crohn (Torkamani, Topol et al. 2008), indicando que essas doenças podem estar relacionadas de alguma forma.

O objetivo do GSA original (Subramanian, Tamayo et al. 2005) era: dado um conjunto de genes, testar se há classes de funções biológicas (vias metabólicas, categorias de Gene Ontology, etc.) em que a expressão desses genes está diferente do esperado. Ou seja, se há genes dentro do conjunto que estão consideravelmente mais expressos ou menos expressos comparados ao padrão (definido a partir de conhecimento biológico a priori).

De maneira simplificada, o GSA verifica se um grupo de genes está fortemente relacionado a uma determinada característica. A forma como esses genes são selecionados pode ser através de um experimento de expressão gênica, genes em algum tecido específico, ou mesmo genes com SNPs associados a uma doença específica. Já as características associadas aos genes podem ser, por exemplo: vias metabólicas, funções biológicas, componentes celulares ou funções moleculares. A análise de conjuntos de genes tem a vantagem de detectar efeitos sutis de um conjunto de SNPs ou genes que poderiam não ser descobertos, avaliando-os individualmente. Em estudos de expressão gênica, na comparação de 
dois ou mais grupos, pode haver dezenas ou centenas de genes que possuem pequenas alterações e, se tomados em conjunto, podem fornecer mais informações sobre os grupos sendo estudados do que se forem levados em conta somente os que possuem grandes alterações (Wang, Li et al. 2007). Em um estudo de diabetes, por exemplo, 22.000 genes foram analisados usando microarray, e após correção para múltipla testagem (Noble 2009), nenhum deles apresentou significância; no entanto, uma abordagem de estudo de vias metabólicas foi capaz de identificar um conjunto de genes responsivos a PGC-1a que mostraram uma sutil (mas consistente no conjunto) diferença em amostras de músculo de pacientes com a doença (Mootha, Lindgren et al. 2003).

O GWAS-GSA (Wang, Li et al. 2007) adaptou o GSA usando o SNP com estatística mais significante (menor $p$-valor) de um gene para calcular a pontuação de enriquecimento (enrichment score). Algumas maneiras de selecionar a estatística (baseada nos p-valores dos SNPs) dos genes contendo mais de um SNP incluem: 1) escolher os $\mathrm{k}$ melhores SNPs (onde k pode ser 1); 2) escolher todos os SNPs com p-valor obedecendo a um limiar pré-definido; ou ainda 3) considerar o p-valor de todos os SNPs no gene. O método testa se um conjunto de genes ou SNPs está relacionado a uma função ou fenótipo. Isso pode acontecer levando em conta somente o conjunto dado (métodos auto-contidos), ou comparando o conjunto com os genes/SNPs fora desse conjunto (métodos competitivos). Pelos exemplos abaixo, retirados do artigo de Fridley e Biernacka (2011), é possível ver uma comparação entre os diferentes métodos. Com quantidades diferentes de SNPs significativos dentro e fora de um conjunto de genes $G$, é possível ver um caso em que não há evidência de enriquecimento (Tabela 1) e um em que há (Tabela 2). Já a Tabela 3 apresenta um método (auto-contido) em que sabe-se a priori a porcentagem esperada de SNPs significativos.

Tabela 1: Método competitivo sem evidência de enriquecimento.

\begin{tabular}{|l|c|c|c|}
\hline & Significativos & Não-significativos & Totais \\
\hline SNPs no conjunto de genes G & 20 & 80 & $\mathbf{1 0 0}$ \\
\hline SNPs fora do conjunto de genes G & 100 & 400 & $\mathbf{5 0 0}$ \\
\hline Totais & $\mathbf{1 2 0}$ & $\mathbf{4 8 0}$ & $\mathbf{6 0 0}$ \\
\hline
\end{tabular}

A mesma porcentagem (20\%) dos SNPs são significativos, tanto no conjunto $G$ quanto fora (ou seja, no conjunto $G$ o número de SNPs significativos não é maior que o esperado, e P >0,001 para o teste exato de Fisher).

Tabela 2: Método competitivo com evidência de enriquecimento.

\begin{tabular}{|l|c|c|c|}
\hline & Significativos & Não-significativos & Totais \\
\hline SNPs no conjunto de genes G & 40 & 60 & $\mathbf{1 0 0}$ \\
\hline SNPs fora do conjunto de genes G & 100 & 400 & $\mathbf{5 0 0}$ \\
\hline Totais & $\mathbf{1 4 0}$ & $\mathbf{4 6 0}$ & $\mathbf{6 0 0}$ \\
\hline
\end{tabular}

Há uma porcentagem (40\%) maior que o esperado (20\% fora de G) dos SNPs são significativos no conjunto $G$. Para esse caso, $P<0,001$ para o teste exato de Fisher. 
Tabela 3: Método auto-contido.

\begin{tabular}{|c|c|c|}
\hline \multicolumn{2}{|c|}{ Número de SNPs no conjunto de genes G significativos com P $<0,05$} \\
\hline & Significativos & Não-significativos \\
\hline Observado & 20 & 80 \\
\hline Esperado & 5 & 95 \\
\hline
\end{tabular}

Seria esperado que $5 \%$ dos SNPs fossem significativos (sob a hipótese nula, ou seja, não havendo associação). No entanto, $20 \%$ dos SNPs o foram. Nesse caso, $P=0,002$ para o teste exato de Fisher, ou seja, há evidência de associação de conjunto de genes com o traço/doença.

Uma limitação dos métodos competitivos é que eles não podem ser aplicados a estudos de conjuntos de genes candidatos em que somente SNPs nesse conjunto foram genotipados. Métodos auto-contidos, por outro lado, podem ser usados tanto em GWAS (sem hipótese a priori) quanto em estudos de conjuntos de genes candidatos (com hipótese a priori).

Ao definir conjuntos de genes para análises, é importante definir claramente seu escopo, tendo em mente que o conhecimento sobre o genoma e as definições sobre conjuntos de genes evoluem e que não há uma definição absoluta para o que estes sejam. Deve-se tomar cuidado ao selecionar bancos de dados que sejam confiáveis, curados e que forneçam listagens mais completas de vias metabólicas e funções biológicas. E, por fim, é importante também reconhecer que a cobertura atual dos genes não é uniforme (há genes e funções que são bem mais estudados que outros), como também não é uniforme a cobertura de SNPs em uma plataforma de GWAS (Fridley e Biernacka, 2011). Na Tabela 4 são listados alguns bancos de dados biológicos comumente usados. Para ver mais detalhes sobre GeneSetAnalysis, sugere-se a leitura de (Wang, Li et al. 2007, Fridley and Biernacka 2011, Maciejewski 2014).

\begin{tabular}{|l|l|}
\hline Banco & Website \\
\hline KEGG & http://www.genome.jp/kegg/ \\
\hline The Gene Ontology project & http://www.geneontology.org/ \\
\hline MetaCore & http://www.genego.com/metacore.php \\
\hline BioCarta & http://www.biocarta.com/genes/index.asp \\
\hline
\end{tabular}

Tabela 4: Alguns bancos de dados de vias metabólicas e funções biológicas.

\section{5 - Uso de interações proteína-proteína como segunda alternativa na priorização de genes}

Além de descobrir quais vias metabólicas podem estar envolvidas com doenças específicas, há a possibilidade de investigar novos genes no contexto das interações de seus produtos, as proteínas. Para isso, é possível usar bancos de dados públicos de interações proteína-proteína baseados em experimentos amplos usando a técnica yeast two-hybrid (Y2H) ou mesmo a busca na literatura. Essas interações 
podem ser modeladas e estudadas usando a teoria dos grafos, que fornecem o amparo matemático para extrair informações relevantes sobre os genes na rede, dependendo de como estão conectados e como se aglomeram em grupos. Dessa forma, é possível descobrir como alterações em um ou mais genes podem interferir em uma rede de interações.

Atualmente, existem bancos de dados que contêm informações sobre interações proteína-proteína (ou PPI, do inglês protein-protein interactions), chamados de interatomas, que contêm dados sobre interações físicas entre proteínas (demonstradas em laboratório e/ou preditas). O conjunto de interações proteína-proteína pode ser modelado como uma rede (também chamada grafo) e algumas características (chamadas de medidas topológicas) dos nós podem ser exploradas (p.ex. número de conexões, coeficiente de agrupamento e outras medidas de centralidade). O interatoma humano é construído com base na coleta de dados reportados na literatura e isto pode trazer um viés no grau de alguns nós, dependendo da doença relacionada. Por exemplo, genes relacionados a câncer, que é uma doença com muitas publicações, tendem a ter mais conexões reportadas do que outros, e isto pode impactar no uso de dados de PPI para outras doenças.

De acordo com a hipótese da localidade, mostrada por Barabási no artigo "Network Medicine: a network-based approach to human disease", em 2011, proteínas relacionadas à mesma doença/fenótipo tendem a interagir ou estar próximas na rede (ver também Zhao, Yang et al. (2011)). Um corolário desse princípio é que mutações em proteínas que interagem frequentemente levam a doenças/fenótipos parecidos. Além disso, no mesmo artigo (Barabasi, Gulbahce et al. 2011) foi mostrado também o princípio da parcimônia, que vias moleculares causais frequentemente coincidem com os caminhos mínimos entre componentes sabidamente associados a uma doença. Com base nesses conceitos, vários métodos foram propostos para analisar os genes na proximidade dos genes que são a priori sabidamente relacionados à doença em questão (métodos locais). No entanto, devido ao viés da literatura, genes muito estudados em geral vão estar em muitas redes, independente dos genes iniciais utilizados. Para contornar esse problema, outros métodos foram propostos para usar caminhos alternativos na rede com o objetivo de priorizar genes com menos conexões, mesmo que estejam um pouco mais distantes (métodos globais).

\section{6 - Descobertas com dados de GWAS e PPI}

Em 2009, Baranzini e colegas usaram dados GWAS de esclerose múltipla (EM) e interações entre proteínas para tentar encontrar funções biológicas comuns em genes agrupados em módulos (ou sub-redes). A hipótese era de que SNPs com bons p-valores, mesmo que não tenham atingido significância em nível genômico, podem trazer informações importantes sobre funções biológicas ou vias metabólicas envolvidas em uma doença. Para isso, eles usaram uma rede de interações protéicas para mapear genes nos quais esses SNPs estavam localizados. Cada gene adicionado a uma sub-rede contribui com o melhor $p$-valor dos SNPs dentro dele para uma medida agregada. Essa medida determina tanto quais os melhores 
genes a serem adicionados à sub-rede quanto o momento em que a mesma para de receber genes, que é quando a medida não cresce mais significativamente.

O trabalho usou SNPs para procurar sub-redes com mais genes do que o esperado ao acaso, associados com EM. Outras abordagens utilizando dados de GWAS e redes PPI foram publicadas com outros transtornos psiquiátricos, como transtorno bipolar (Akula, Baranova et al. 2011), esquizofrenia (Jia and Zhao 2012) e autismo (Lee, Raygada et al. 2012). 


\section{Capítulo 3 - Estudos genéticos em TDAH}

O Transtorno de Déficit de Atenção e Hiperatividade (TDAH) é a condição psiquiátrica mais comum na infância e na adolescência (Lesch, Timmesfeld et al. 2008), afetando cerca de $5,3 \%$ de crianças e adolescentes em todo o mundo (Polanczyk and Rohde 2007) e 5,8\% na população brasileira (Polanczyk et al., 2010). É um transtorno caracterizado pelo desenvolvimento inapropriado e sintomas alterados em duas dimensões do comportamento - atenção e hiperatividade/impulsividade.

O TDAH tem sido visto como um transtorno poligênico e multifatorial (Yang, Neale et al. 2013). Tanto variações raras quanto comuns contribuem para sua etiologia complexa (Poelmans, Pauls et al. 2011, Stergiakouli, Hamshere et al. 2012, Williams, Franke et al. 2012). Fenotipicamente, varia de leve a grave. O efeito epistático ou pleiotrópico atuando em conjunto com o meio ambiente pode explicar sua alta comorbidade com outros distúrbios psiquiátricos (Rietveld, Hudziak et al. 2004).

Diversos genes candidatos para o TDAH foram relacionados à via dopaminérgica (DAT1, DRD4 e DRD5), noradrenérgica (DBH) e serotonérgica (HTR1B, 5HTT), uma vez que estudos neurobiológicos sugerem um importante papel destes neurotransmissores na fisiopatologia do transtorno (Banaschewski, Becker et al. 2010, Tong, McKinley et al. 2015).

O sistema dopaminérgico está particularmente envolvido na fisiopatologia do TDAH, pois desempenha funções essenciais para a seleção, iniciação e manutenção de funções motoras, assim como regulação de funções cognitivas, exercendo um papel crucial nos mecanismos de recompensa cerebral, modulando a saliência de estímulos e a motivação relacionada a eventos (Berridge and Robinson 1998)(Berridge e Robinson, 1998). Entretanto, embora associações positivas com polimorfismos próximos, ou mesmo no interior destes genes, tenham sido relatadas por estudos independentes, não houve sucesso em replicar tais resultados mesmo ampliando o tamanho amostral (Palmer, Bailey et al. 1999, Holmes, Payton et al. 2000, Yang, Chan et al. 2007, Spencer, Biederman et al. 2013). Apesar de a via dopaminérgica estar claramente relacionada com a doença, principalmente pela conhecida ação de medicamentos usados na mesma, estudos de genômica em larga escala têm implicado outras vias em TDAH. Entretanto, ainda que não somente genes relacionados a vias de neurotransmissores, mas também genes relacionados ao neurodesenvolvimento e sinaptogenese tenham apresentado resultados positivos, a replicabilidade dos mesmos nos diferentes estudos, tanto para avaliação de alterações comuns, raras ou de novo, continua pequena (Yang, Neale et al. 2013, Hawi, Cummins et al. 2015, Zayats, Athanasiu et al. 2015).

\section{1 - Estudos de GWAS - Variantes Comuns}

Levando-se em conta evidências de que o TDAH é um transtorno multigênico e multifatorial, nos últimos anos começaram a surgir GWASs em TDAH. O primeiro 
estudo de GWAS em TDAH, realizado em novembro de 2008, sugeriu genes de risco para TDAH analisando 343 pacientes adultos e 250 controles. Entretanto nenhum SNP atingiu resultado significante (Lesch, Timmesfeld et al. 2008).

O primeiro trabalho de TDAH realizado com crianças e adolescentes por GWAS foi publicado um mês mais tarde, e realizado pelo Genetic Association Information Network (GAIN) e utilizou as amostras do International Multicentre ADHD Genetics (IMAGE) project (disponível em http://www.ncbi.nlm.nih.gov/projects/gap/ cgi-bin/study.cgi?study_id=phs000016.v1.p1). Esse trabalho analisou 958 trios e não encontrou nenhum SNP estatisticamente significante a nível genômico (Neale et al., 2008). Eles apresentam uma tabela com os 25 SNPs que atingiram os menores p-valores na análise de TDT (transmission disequilibrium test - teste de transmissão de desequilíbrio), sendo que nenhum é maior que $10^{-5}$. Lasky-Su e colegas (2008) analisaram os mesmos trios, porém usando diagnóstico dimensional (6 fenótipos quantitativos baseados em 18 sintomas) e não categorial, e identificaram 2 SNPs, rs6565113 e rs552655, que atingiram significância para um fenótipo específico. Estes SNPs estavam localizados em íntrons dos genes CDH13 e GFOD1, respectivamente.

Os SNPs sugeridos no estudo de Neale e colegas (2008) foram testados em 415 trios por um grupo independente, e nenhum dos SNPs mostrou-se associado com a doença (Lantieri, Glessner et al. 2010). A ausência de achados significativos se repetiu também em outras pesquisas, como a realizada pelo IMAGE I/ consortium sample (896 casos com TDAH e 2455 controles), e ainda a realizada pelo consórcio PUWMa (Pfizer-funded study from the University of California, Los Angeles, Washington University, and Massachusetts General Hospital). Neste último, um dos 20 SNPs com menor $p$-valor estava localizado em um gene associado com TDAH, o SLC9A9 (Mick et al., 2010). Este gene já havia sido previamente descrito como um gene envolvido com TDAH em um estudo familial (de Silva, Elliott et al. 2003) e em outros estudos de associação (Brookes, Xu et al. 2006, Lasky-Su, Anney et al. 2008, Lasky-Su, Neale et al. 2008).

As variantes comuns para TDAH podem ser de efeito muito pequeno e, portanto, exigem um número amostral muito grande para serem detectadas de forma segura. Assim, a partir dos achados de variantes comuns revelados por GWAS, uma meta-análise foi realizada onde foram analisadas todas as amostras agrupadas: 2064 trios, 896 casos e 2455 controles (Neale, Medland et al. 2010). Ainda assim, não foram encontrados SNPs com p-valor significante a nível genômico.

\subsection{1 - Análise de conjuntos de genes em dados de GWAS de TDAH}

Uma vasta literatura tem surgido mostrando algoritmos e integração de diferentes bancos de dados para priorizar variações e genes para a compreensão de doenças complexas, inclusive psiquiátricas (Baranzini, Galwey et al. 2009, Akula, Baranova et al. 2011, Poelmans, Pauls et al. 2011, Rossin, Lage et al. 2011, Chang, Zhang et al. 2012, Jia and Zhao 2012, Lee, Raygada et al. 2012). Nos trabalhos relacionados a TDAH, Chang e colegas (2012) uniram os achados anteriores relacionados à doença, criando um banco de dados público (ADHDgene, disponível em http://adhd.psych.ac.cn). O grupo também reportou uma lista de genes 
potencialmente relacionados a TDAH ("hot genes list"), baseada na interseção de cinco ferramentas de priorização de genes. No entanto, como esta lista é baseada em estudos de associação de genes candidatos e em dados de GWAS e o número de vezes que o gene foi reportado com algum resultado positivo é levado em conta na priorização, é claro que genes provindos de estudos de associação de genes candidatos sempre serão melhores ranqueados, uma vez que existem mais estudos deste tipo até o momento, e todos com foco nos mesmos candidatos.

Poelmans e colegas (2011) usaram os resultados de cinco GWAS de TDAH para buscar funções biológicas e vias com o objetivo de reanalizar os achados conjuntamente. Eles realizaram uma busca sistemática na literatura por funções (putativas) das proteínas codificadas pelos 85 melhores genes desses GWASs. Apesar de reportarem um modelo (em que os genes ligados a crescimento de neutritos seriam os principais genes relacionados ao TDAH), nenhum modelo matemático reprodutível foi proposto, tendo sido os resultados alcançados quase que por um processo manual de análise de vias biológicas.

\section{2 - A importância das mutações pontuais de novo}

As mutações de novo representam a forma mais extrema de variação genética rara: em média elas são mais prejudiciais do que as variações hereditárias comuns porque foram submetidas a pressão seletiva mais rigorosa (Crow 2000, Eyre-Walker and Keightley 2007). Isso faz com que essas mutações candidatas a causar doenças genéticas ocorram esporadicamente. De fato, estudos recentes revelaram variantes de nucleotídeos únicos de novo como a principal causa de síndromes raras esporádicas (Hoischen, van Bon et al. 2010, Ng, Bigham et al. 2010, Hoischen, van Bon et al. 2011). Uma vez que as mutações de novo, coletivamente, não são consideradas eventos raros, pois admite-se que existam 2 mutações de novo em regiões codificadoras do genoma por zigoto, então é possível que estas sejam responsáveis por uma fração importante de doenças comuns (Awadalla, Gauthier et al. 2010).

Em adição, o uso de novas tecnologias, como o sequenciamento de alta cobertura (ou de próxima geração - High-Throughput Sequencing ou Next Generation Sequencing), permite um aumento significativo da capacidade de examinar a contribuição de variantes raras, assim como as variantes comuns, no desenvolvimento de doenças complexas. A vantagem dessas tecnologias de sequenciamento paralelo massivo é uma redução dos custos e aumento da cobertura em larga escala, caracterizando uma ferramenta poderosa para identificar mutações envolvidas em uma dada condição (Sobreira, Cirulli et al. 2010). É essa tecnologia que vem sendo utilizada no projeto 1000 genomas, cujos resultados piloto foram recentemente publicados (Abecasis, Auton et al. 2012).

Ainda, o desenvolvimento de métodos de captura de alvos específicos e sequenciamento paralelo massivo de DNA, tornou possível determinar eficientemente quase toda a variação em regiões codificadoras num genoma humano individual, em um processo chamado de sequenciamento de exoma (exome 
sequencing). Esse processo se trata do sequeciamento apenas das regiões codificantes do genoma (cerca de 1\%), que são os exons. Esta nova técnica é uma poderosa abordagem para identificação de genes determinantes de distúrbios Mendelianos, assim como de doenças complexas, que não puderam ser identificados por outros métodos (Bamshad et al., 2011). Apesar de conter uma parte tão pequena do genoma, estima-se que a região dos exons contêm cerca de 85\% das alterações causadoras de doenças (Choi et al., 2009).

O sequenciamento de exoma tem sido utilizado para identificar a base genética de doenças em que um certo número de genes estão associados a um fenótipo amplo, tal como doenças imunológicas (Bolze et al., 2010; Byun et al., 2010), deficiência intelectual (Shoubridge et al., 2010; Abou Jamra et al., 2011; Çalışkan et al., 2011) e predisposição a câncer (Link et al., 2011). Ainda, vários estudos-piloto revelaram recentemente que as mutações de novo afetam genes diferentes em indivíduos distintos e juntas poderiam explicar uma proporção das doenças comuns do neurodesenvolvimento, como a deficiência intelectual (Vissers et al., 2010), espectro autista (Iossifov et al., 2012; Neale et al., 2012; O'Roak et al., 2012; Sanders et al., 2012) e esquizofrenia (Girard et al., 2011; Xu et al., 2011). Os dados de exoma estudados nesse trabalho foram os primeiros gerados em trios de TDAH na literatura. 


\section{Capítulo 4 - Integração de dados}

\section{biológicos}

Este capítulo tem como objetivo revisar alguns tipos de dados biológicos no contexto de genética e genômica. Também serão mostradas as limitações e dificuldade de se integrar tais dados, bem como quais técnicas podem ser utilizadas para diminuir erros. O anúncio da conclusão do genoma humano no ano 2000 foi um marco para a história da nossa espécie (Lander, Linton et al. 2001, Venter, Adams et al. 2001). Apesar de a sequência não ter sido completamente montada, a sequência parcial dos nossos cromossomos já mostrava a identificação e posição relativa de inúmeros genes presentes em nosso DNA.

Desde então, muitos outros projetos colaborativos vêm sendo desenvolvidos para aumentar a compreensão dos sistemas moleculares dos seres humanos e de outras espécies (Birney, Stamatoyannopoulos et al. 2007, Razick, Magklaras et al. 2008, Abecasis, Altshuler et al. 2010, International HapMap 3 Consortium, Altshuler et al. 2010, Abecasis, Auton et al. 2012, ENCODE Project Consortium 2012, Lonsdale, Thomas et al. 2013, Croft, Mundo et al. 2014, GTEx Consortium 2015). Em tais trabalhos, diversos laboratórios localizados em diferentes partes do mundo realizam experimentos que se complementam para que determinada análise seja feita com um maior poder de informação, estatística ou confirmação biológica. No caso dos projetos HapMap (International HapMap 3 Consortium, Altshuler et al. 2010) e 1000 genomas (Abecasis, Auton et al. 2012), por exemplo, foi feito o sequenciamento e análise do genoma de indivíduos de diversas ancestralidades, fato que tornou necessária a participação de diferentes grupos de pesquisa. Os projetos citados consistiram na identificação dos polimorfismos de único nucleotídeo mais comuns em diferentes populações, como a africana, a chinesa, e a europeia, dentre outras.

Para que esses dados fossem gerados e disponibilizados facilmente para a comunidade científica, foi necessária a criação de um padrão de armazenamento que, dado um conjunto de diferentes genomas, mostrasse para cada variação, informações importantes como: o cromossomo, a posição cromossômica, o alelo referência, o alelo alternativo, o código identificador da variação, a frequência da variação em diferentes populações, para citar alguns. Dessa maneira, surgiu o tipo de arquivo VCF (do inglês Variant Call Format) que contém essas e outras informações e vem sendo usado desde a criação do projeto 1000 genomas para esse tipo específico de dados. Nessa mesma época, outros formatos de arquivo foram criados, como o tipo de arquivo SAM (http://samtools.github.io/htsspecs/SAMv1.pdf), para mostrar o alinhamento de sequências no genoma, e o tipo de arquivo BED (https://genome.ucsc.edu/FAQ/FAQformat.html\#format1), que é usado para guardar intervalos cromossômicos, e muito útil para o estudo de variações de número de cópias. Tem sido feito um esforço na comunidade de bioinformática e genômica para manter ou aprimorar tais padrões para que as diferentes ferramentas de análise desenvolvidas ao longo dos últimos anos continuem funcionando corretamente. 
O mesmo ocorre quanto a bancos de dados com informações sobre genes (ex: http://www.ncbi.nlm.nih.gov/gene). Nosso conhecimento a respeito desse campo ainda é muito limitado e, dada a importância desse tipo de informação, atualizações são realizadas diariamente. Dessa forma, o padrão na escolha de nomes e identificadores torna-se fundamental para que a consistência seja mantida. Infelizmente, a criação de diversos sistemas com informações sobre os mesmos tipos de dados pode gerar inconsistência ou redundância entre as variadas bases, como por exemplo o sistema Entrez (http://www.ncbi.nlm.nih.gov/books/NBK3837/), do Centro Nacional para Informação de Biotecnologia dos Estados Unidos (ou National Center for Biotechnology Information, o NCBI), e o EnsEMBL (http://www.ensembl.org), do Laboratório Europeu de Biologia Molecular (ou European Molecular Biology Laboratory, o EMBL). Cuidados adicionais devem ser tomados ao se unir informações dessas bases, como a verificação da data de atualização e a correspondência dos identificadores de um banco com o(s) outro(s) sendo utilizados.

A consistência nos identificadores desses dados se faz ainda mais importante quando outros bancos utilizam essas informações. Bancos de dados como a Gene Ontology, mais conhecida como GO (Ashburner, Ball et al. 2000), e a Kyoto Enclopedia of Genes and Genomes, mais conhecida como KEGG (Kanehisa and Goto 2000), lançam mão desses identificadores para manter sua coleção igualmente consistente. Isso é fundamental quando há uma relação entre dados de diferentes origens e em diferentes contextos biológicos. Bancos de dados de interação proteína-proteína (Razick, Magklaras et al. 2008), por exemplo, trazem interações em nível proteômico. Cada proteína, porém, está ligada a um gene, que por sua vez faz parte do contexto genômico. Os genes podem estar mais expressos ou menos expressos - contexto transcritômico - em certos tecidos, que compõem o contexto celular e histológico. Portanto, dada a conexão e interdependência entre os diferentes contextos biológicos, a manutenção do padrão de representação da informação biológica é primordial.

Uma outra preocupação que se deve ter na integração de dados biológicos é a união de elementos do mesmo tipo gerados por plataformas ou tecnologias diferentes. Consideremos o caso dos dados de expressão gênica, que inicialmente era somente gerados pela tecnologia de microarranjos (ou em inglês microarray) e hoje em dia são gerados majoritariamente pela tecnologia de sequenciamento em larga escala, ou mais especificamente RNA-Seq (Wang, Gerstein et al. 2009), no caso de dados de RNA. O primeiro mede a abundância de RNA usando o valor de um sinal luminoso gerado através de hibridação de probes com fluoróforos especiais e lido por um scanner. Já na técnica mais atual, é levada em consideração a contagem das sequências mapeadas na região de genes específicos para medir o quanto estes estão expressos. No entanto, nem sempre o surgimento de um método inovador significa a rejeição e abandono dos métodos antigos. O banco de dados Gene Expression Omnibus (ou GEO, http://www.ncbi.nlm.nih.gov/geo/) contém milhares de amostras de experimentos de expressão gênica advindas de diversos pacientes e tecidos que foram submetidos ao longo dos anos e ainda estão disponíveis. O artigo de Chavan e colegas (2013) dá uma visão geral sobre a 
integração de dados de microarranjos com dados de RNA-Seq, bem como métodos utilizados para a análise.

Algo semelhante à análise de expressão gênica ocorre quanto comparamos os dois principais métodos de identificação de variação de número de cópias (ou CNVs, do inglês copy-number variants) usando dados gerados por arranjos de SNPs (ou SNP-arrays) e dados gerados através de sequenciamento de exoma. A primeira limitação está relacionada às diferentes técnicas utilizadas. Semelhante à detecção de expressão gênica por microarranjos, um sinal luminoso informa quais variantes estão presentes nas sequências hibridizadas no SNP-array. Dessa forma, é possível identificar os alelos e, pela intensidade do sinal luminoso, também é possível estimar o número de cópias na região (Wang, Li et al. 2007). Na verdade, essa técnica foi desenvolvida para a identificação de SNPs (variações comuns), e a localização dos mesmos no genoma depende da plataforma utilizada e tem uma distância fixa prédeterminada. Os dados de exoma, da mesma forma, são utilizados para encontrar variações de único nucleotídeo. No entanto, a cobertura nas regiões dos exons também vem sendo utilizada para a identificação do número de cópias do genoma (Fromer and Purcell 2014). Além da limitação das tecnologias diferentes, há a limitação em relação às regiões utilizadas. Enquanto os SNP-arrays usam posições em que há polimorfismos comuns, dados de exoma só consideram regiões com exons. Uma maneira de integrar os dois tipos de análise, é considerar a interseção entre regiões e o número estimado de cópias na região. Dessa forma, pode-se por exemplo considerar somente regiões de CNVs que estejam presentes nos dois tipos de análise.

Finalmente, é preciso enfatizar que algumas medidas precisam ser tomadas para a diminuição de erros na integração de dados. Quando se deseja fazer uso de dados vindos de diferentes técnicas ou diferentes plataformas, o uso de métodos matemáticos mais elaborados são necessários (Gomez-Cabrero, Abugessaisa et al. 2014). Uma vantagem que existe em análise de número de cópias ou variações de único nucleotídeo é que o resultado final é um valor discreto: para os CNVs, pode ser nenhuma cópia, 1 cópia, 2 cópias, 3 cópias, etc., e para os SNVs, heterozigoto ou homozigoto (para a referência ou para a alteração). Já em dados de interação proteína-proteína, é possível fazer uso de uma coleção de diferentes bancos e verificar a concordância entre eles de alguma forma. O banco iReflndex (Razick, Magklaras et al. 2008), por exemplo, contém a união de 9 bancos diferentes com o mesmo tipo de dado, mas a interseção entre os mesmos está longe, e é possível aplicar vários filtros para que apenas um subconjunto mais confiável dessas interações seja utilizada. Dado que as técnicas utilizadas podem conter erros, exigir uma confirmação entre diferentes bancos é de extrema importância para diminuir o número de interações falsamente positivas. 


\section{Capítulo 5 - Metodologia}

Para comparar genes relacionados a diferentes tipos de variações, foi realizada uma análise de exoma em famílias brasileiras cujo probando tivesse TDAH esporádico. Em paralelo à análise de exoma, foi feita uma consulta ao banco de dados de variações genéticas ADHDgene. Dessa forma, foi possível usar tanto dados gerados por nosso grupo quanto dados gerados anteriormente por outros grupos de pesquisa. Além disso, dados de interação proteína-proteína foram usados para construir a sub-rede de genes diretamente relacionados com os genes de TDAH e para verificar a localização relativa e a classificação topológica dos genes sementes na rede. Como etapa final, foi realizada uma análise de funções biológicas, vias, bandas citogenéticas e doenças que podem estar relacionadas aos genes.

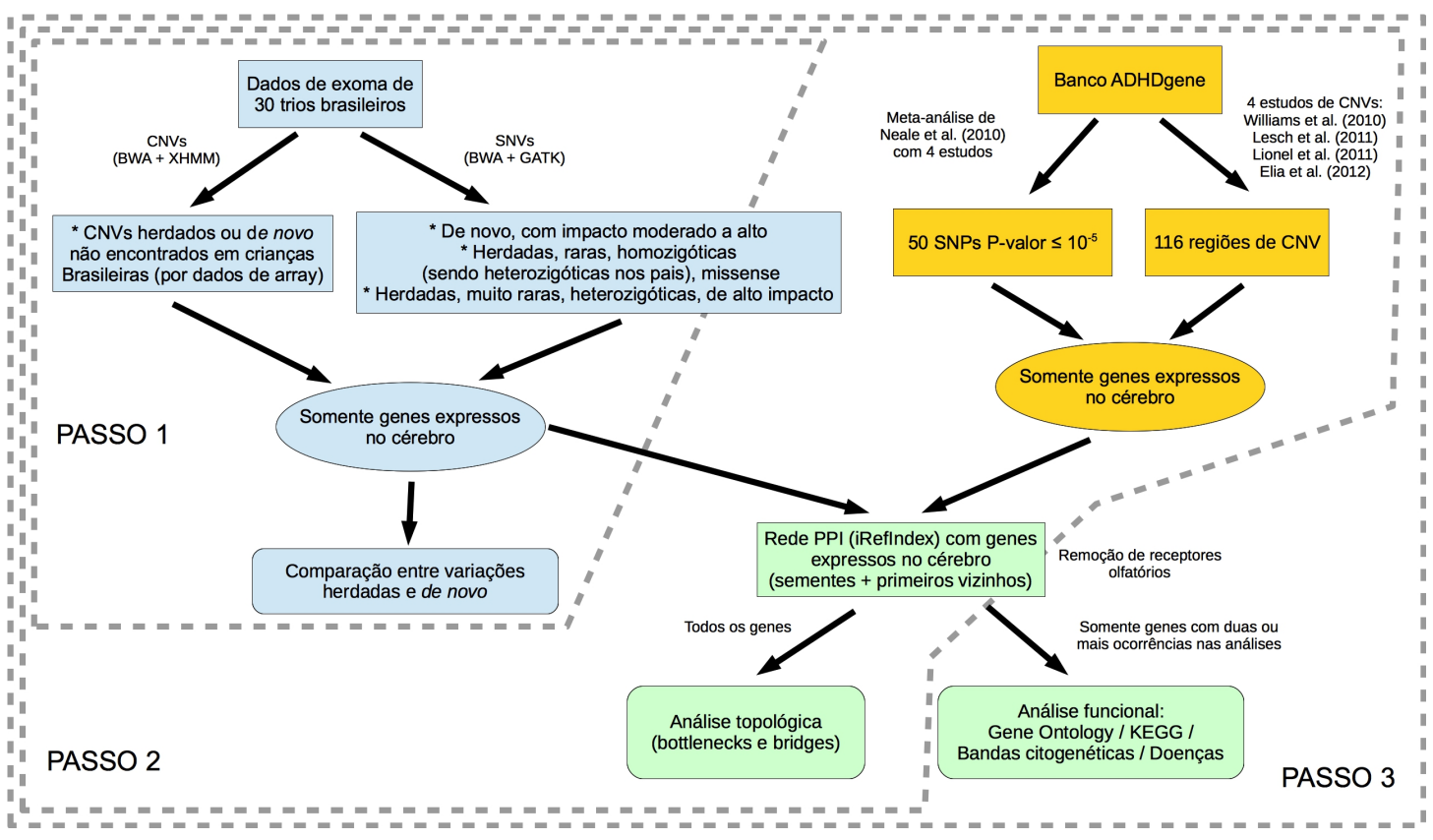

Figura 2. Visão geral das análises realizadas nesse trabalho. Os elementos em azul são os conjuntos de dados e análises realizadas com os genes das variantes de dados públicos ou presentes nos exomas de crianças brasileiras. As caixas amarelas são os dados provenientes de bancos de dados públicos. As caixas verdes são os dados provenientes dos exomas de trios brasileiros.

\section{1 - Dados de expressão gênica em cérebro}

As amostras dos bancos BrainSpan Atlas of the Developing Human Brain (http://brainspan.org), Allen Human Brain Atlas (http://human.brain-map.org) e GTEx Portal (http://www.gtexportal.org) foram usadas para verificar quais genes estão expressos no cérebro. Cada gene foi considerado expresso caso tivesse o índice de fragmentos por milhão (RPKM, da sigla em inglês para "reads per kilobase per million") maior que 1 em qualquer uma das amostras (que tem origem em diferentes regiões do encéfalo e possuem diferentes idades).

\section{2 - Construção do interatoma humano}


Para construir as redes de interação proteína-proteína, foi usada a compilação de bancos de dados do site iReflndex. Esta compilação une dados dos principais bancos de dados com esse tipo de informação: BIND (Bader, Betel et al. 2003), BioGRID (Stark, Breitkreutz et al. 2006), CORUM (Ruepp, Brauner et al. 2008, Ruepp, Waegele et al. 2010), DIP (Salwinski, Miller et al. 2004), HPRD (Keshava Prasad, Goel et al. 2009), IntAct (Kerrien, Aranda et al. 2012), MINT (Licata, Briganti et al. 2012), MPPI (Pagel, Kovac et al. 2005) e OPHID (Brown and Jurisica 2005). Usamos somente ligações com pelo menos duas fontes de evidência de interação física entre as proteínas do par correspondente. A rede foi tratada como um grafo não-direcionado.

\section{3 - Medidas topológicas usadas na rede}

O grau (k) de um nó é a quantidade de ligações (ou vizinho que ele tem)

- A centralidade entre-nós (ou betweenness centrality) é uma fração de quantos caminhos mínimos na rede passam por um nó $i$ :

$$
C_{i}^{B t w}=\sum_{j=1}^{N} \sum_{k=1}^{j-1} \frac{g_{j k}(i)}{g_{j k}},
$$

em que $g_{\mathrm{jk}}(\mathrm{i})$ é o número de caminhos mínimos do nó $j$ ao nó $k$ passando por $i$ e $g_{\mathrm{jk}}$ é o total de caminhos mínimos entre $j$ e $k$. A centralidade entre-nós mede a importância global de uma proteína em comunicar outros pares de proteínas na rede (Yu et al., 2007; Freeman, 1977). Nós com valor alto de centralidade entre-nós foram chamados de "gargalos", devido ao seu papel de conectar proteínas com propriedades essenciais funcionais e dinâmicas (Barabási et al., 2011).

- O coeficiente de agrupamento de um nó $\boldsymbol{i}$ (clustering coefficient) indica o quanto a vizinhança deste nó está conectada entre si. De forma simplificada, é uma razão do número de arestas que existem entre os vizinhos de $i$ pelo total que poderiam existir:

$$
C_{i}^{C l u}=\frac{2 \mathrm{n}}{k_{i}\left(k_{i}-1\right)^{\prime}}
$$

em que $n$ é o número de arestas entre os vizinhos de $i$ ek $k_{i}$ é o grau do nó i. Essa medida também varia entre 0 e 1 . O zero indicando que os vizinhos de i não se ligam e 1 indicando que todos se ligam. Essa medida indica o grau de interconectividade na vizinhança de um nó (Watts e Strogatz, 1998).

- A medida do nó corretor de um nó $i$ (brokering) (Cai, Borenstein et al. 2010) mede se um nó tem muitos vizinhos que não se conectam. Essa medida usa o grau e o coeficiente de agrupamento para ser calculada:

$$
\text { Brokering }(i)=\left(1-C_{i}^{C l u}\right) \times k_{\text {norm }}(i)
$$

em que $k_{\text {norm }}$ é o grau do vértice $i$ dividido pelo maior grau na rede. Cai e colegas (2010) mostraram que genes relacionados a doenças tendem a ter a característica de nó corretor, e que essa propriedade se mantém robusta mesmo com o viés da literatura presente no interatoma.

Estas análises topológicas servem como um meio para se compreender o papel de cada nó na rede. Vários estudos (Goh, Cusick et al. 2007, Cai, Borenstein et al. 2010, Barabasi, Gulbahce et al. 2011) sugerem que proteínas com um número grande de interações (chamadas "hubs") são mais críticas. A perda destes hubs poderia implicar morte ou defeitos de desenvolvimento de organismos. O uso de 
características topológicas em redes biológicas permite que diferentes nós exercendo diferentes papéis possam ser priorizados dentro de um conjunto.

\section{4 - Genes relacionados a polimorfirmos de único nucleotídeo de dados públicos}

Como genes relacionados a polimorfismos de único nucleotídeo (ou SNPs, do inglês single-nucleotide polymorphisms) publicados por outros grupos de pesquisa, foram selecionados os 50 SNPs resultantes da meta-análise de Neale et al. (2010a) com $p$-valor $\leq 10^{-5}$. Essa meta-análise incluiu somente crianças e jovens em estudos que usam as mesmas variáveis categóricas de diagnóstico, diminuindo dessa forma as chances de heterogeneidade fenotípica. Foram usados dados de quatro projetos: a) do Children's Hospital of Philadelphia (CHOP); b) fase I do International Multicenter ADHD Genetics project (IMAGE); c) fase II do IMAGE (IMAGE II); e d) o estudo financiado pela Pfizer da Universidade da Califórnia (Los Angeles), da Washington University, e do Massachusetts General Hospital (PUWMa). A amostra final consistiu de 2064 trios, 896 casos, e 2455 controles. Do conjunto inicial de 50 SNPs, foram utilizados os 14 genes reportados pela meta-análise de Neale et al. (2010), que são os genes em que esses SNPs estão contidos.

\section{5 - Genes em regiões com variação de número de cópias de dados públicos}

Para estudar o papel de variações raras, foram selecionados do site ADHDgene os estudos com CNVs que usaram amostras de crianças e adolescentes com ancestralidade predominantemente caucasiana. Os CNVs são dos seguintes estudos: 57 CNVs de Williams, Zaharieva et al. (2010), 17 CNVs de Lesch, Selch et al. (2011), 23 CNVs de Lionel, Crosbie et al. (2011) e 19 CNVs de Elia, Glessner et al. (2012). A partir das regiões de CNVs publicadas nesses estudos, buscamos os genes que estavam localizados nesses regiões. Além das informações presentes nestas tabelas também foram capturadas as variáveis referentes a posição dos CNVs e o Symbol in Literature deles. Estas foram encontradas na página de cada um dos CNVs. No caso dos CNVs do estudo de Lionel et al. (2011) as posições destes estavam ausentes (começavam e terminavam em zero). Utilizando a tabela presente no material suplementar do artigo e o Symbol in Literature do ADHDgene foi possível encontrar as posições dos mesmos. Os CNVs tinham suas posições anotadas de acordo com a versão do genoma usada no estudo ( $h g 17$ e $h g 18$ ). Como os outros bancos de dados aqui utilizados usam uma versão mais recente (hg19), foi necessário fazer a conversão das versões mais antigas para a versão hg19. Isto foi realizado pela função liftOver do pacote rtracklayer (Michael Lawrence 2009). A função aplica o mesmo algoritmo usado pela UCSC em sua página (disponível em http://genome.ucsc.edu/cgi-bin/hgLiftOver). Genes presentes dentro da região dos CNVs foram obtidos a partir do banco de dados Ensembl acessado via o pacote biomaRt (Durinck, Spellman et al. 2009).

\section{6 - Seleção e coleta das amostras brasileiras}

Foram selecionadas 36 famílias com crianças com o diagnóstico clínico de TDAH, sem história familiar (casos esporádicos). A amostra desse projeto foi proveniente da 
"Coorte de Escolares de Alto Risco para o desenvolvimento de Psicopatologia e Resiliência na Infância - o estudo "PREVENÇÃO" do Instituto Nacional de Psiquiatria do Desenvolvimento (INPD). Desses 36 trios iniciais, 26 são de crianças do sexo masculino e 10 de crianças do sexo feminino, com idades entre 6 e 13 anos com uma média de idade de 9,45 anos, na data da coleta. A idade dos pais, no momento do nascimento, teve uma média de 24,6, variando entre 40 a 15 anos (mãe) e uma média de 27,8, variando entre 39 a 16 anos (pai). Quanto aos fatores de risco, sete mães afirmaram ter feito uso de tabaco durante a gestação e apenas uma de uso de álcool. Nove mães afirmaram ter tido pré-eclâmpsia e três diabetes gestacional.

A maioria dos casos (15 pacientes) possuía o subtipo de TDAH combinado, seguido do subtipo desatento com 14 pacientes e o subtipo hiperativo/impulsivo foi encontrado em apenas 6 pacientes. Dezoito pacientes apresentaram comorbidades que variaram de 1 a 4 comorbidades, sendo a mais frequente 0 transtorno desafiador opositor, presente em 10 pacientes, seguido de transtorno emocional em 7 pacientes segundo o agrupamento proposto pelo DAWBA - termo inglês Development and Well-Being Assessment, que significa avaliação de desenvolvimento e bem-estar.

\section{7 - Extração de DNA}

Todas as amostras do presente estudo passaram pela etapa de extração de DNA, juntamente com todos os indivíduos coletados da coorte PREVENTION utilizando o método e os reagentes fornecidos pelo fabricante do kit OraGene DNA collection kit (DNA genotek).

Uma primeira avaliação a cerca de integridade do DNA extraído foi realizada através da visualização das amostras em gel de agarose $1 \%$ preparado com TAE $1 \mathrm{X}$ (Tris 40mM; Ácido Acético Glacial 20mM; EDTA 1mM; pH 8,0) contendo brometo de etídio $1 \mathrm{mg} / \mathrm{ml}$ (Sigma ${ }^{\circledR}$, St. Louis, MO, EUA) com um marcador de peso molecular de 100 pares de base.

Ainda, para a uma segunda avaliação de qualidade e a quantidade utilizamos a espectrofotometria através da leitura da absorbância nos comprimentos de onda de 260 e 280 nanômetros utilizando espectrofotômetro (NanoDrop $\AA$ ND-1000). O grau de pureza do DNA foi avaliado com base na razão entre as leituras de 260 e $280 \mathrm{~nm}$, uma vez que valores superiores a 1,8 para essa relação sugerem que o DNA está essencialmente puro e passível de ser utilizado. As amostras extraídas tiveram uma média de quantidade $375,65 \mathrm{ng} / \mathrm{ul}$, onde o mínimo de 25,9 ng/ul, a máxima foi de $3.532,7 \mathrm{ng} / \mathrm{ul}$.

\section{8 - Construção das bibliotecas e enriquecimento}

Para as etapas de construção das bibliotecas e enriquecimento destas com sequências exclusivamente de regiões exônicas, foi utilizado o kit Nextera ${ }^{\circledR}$ Exome Enrichment Kit (Illumina Inc., San Diego, USA) segundo protocolo do fabricante.

O preparo das bibliotecas foi feito cobrindo uma região alvo (target) de 62 Mb, 20.794 genes, 201.121 exons. As amostras foram combinadas em pools de 12 amostras, onde cada amostra é marcada com um index para posterior identificação. 
A validação da biblioteca pronta foi feita via Bioanalyzer e a quantificação da biblioteca via PCR em tempo real, como demonstrada na Figura 3. Não obtivemos sucesso em um trio (paciente e mãe) na construção da biblioteca. Este trio foi excluído da análise.

\section{9 - Sequenciamento e mapeamento do exoma}

O sequenciamento completo do exoma foi realizado conforme as recomendações do fabricante, na plataforma IlluminaHiScan $S^{\mathrm{TM}}$ (Roche Technologies), para os oito primeiros trios. Essa tecnologia foi substituída pelo equipamento HiSeq $2500^{\mathrm{TM}}$ (Illumina, Inc.) para os próximos 27 trios. Foi utilizada a metodologia de sequenciamento pareado.

As sequências foram mapeadas utilizando como referência a montagem do National Center for Biotechnology Information (NCBI) reference human genome build 37 (GRCh37/hg19) usando-se o software Burrows-Wheeler Aligner, ou BWA (Li and Durbin 2009).

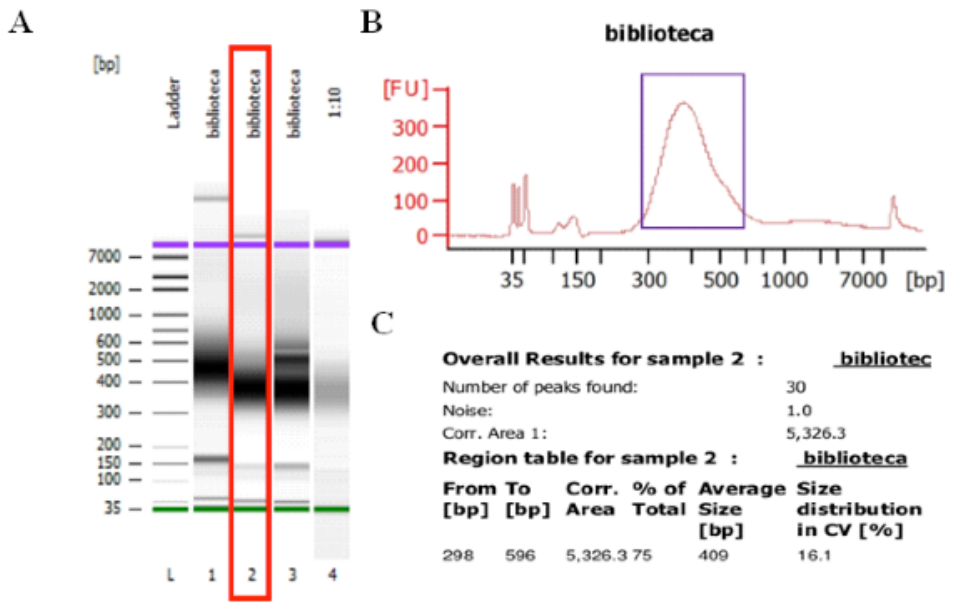

Figura 3. Análise de 3 bibliotecas realizadas no Bioanalyzer para cálculo do tamanho médio dos fragmentos. a) Imagem da corrida de eletroforese do equipamento demonstrando o intervalo de fragmentação (destacada pelo retângulo vermelho); b) Curva de concentração (pg/ulx1000) dos fragmentos da biblioteca de acordo com tamanhos observados; c) Informações referentes ao pico de interesse (destacado pelo retângulo roxo), que representa $75 \%$ do total de fragmentos, incluindo o tamanho médio. 0 tamanho dos fragmentos recomendado pelo fabricante é > 350 pb (o que leva em conta o tamanho dos fragmentos de exons de 200 300 mais adaptadores e indexes).

\subsection{0 - Variações de único nucleotídeo nos exomas de trios brasileiros}

A detecção de variações de único nucleotídeo foi feita usando-se o programa GATK Unified Genotyper (DePristo, Banks et al. 2011) seguindo as recomendações de boas práticas (Van der Auwera, Carneiro et al. 2013) desenvolvidas pelos desenvolvedores do mesmo. Em seguida, foi feita uma análise de parentesco utilizando o programa KING (Manichaikul, Mychaleckyj et al. 2010). Em um caso ideal, é esperado que a relação de parentesco calculada por esse programa tenha valor próximo a 0,25 . Trios em que esse valor foi menor que 0,19 foram removidos das análises. Para anotação das variações, foram utilizados os programas Annovar (Wang, Li et al. 2010) e SnpEff (Cingolani, Platts et al. 2012). Para classificar as 
variações por tipos de frequência, usamos a frequência do menor alelo dado pelo banco ExAC (Exome Aggregation Consortium 2015). Variações foram chamadas de "raras" se apareceram com frequência entre $1 \%$ e $5 \%$, "muito raras" se a frequência encontrada estava abaixo de $1 \%$ e "novas" se a frequência não foi encontrada no banco de dados.

Após a anotação, foi feita uma busca por variações de três tipos que poderiam contribuir para o desenvolvimento da doença: 1. variações de novo com impacto de moderado a alto (missense, nonsense ou splice site); 2. variações raras, de impacto moderado (missense), que são homozigóticas na criança e heterozigóticas nos pais; e 3. variações muito raras, de alto impacto (nonsense ou splice site) heterozigóticas na criança.

\subsection{1 - Variações de número de cópias nos dados de array de amostras controles brasileiras}

Foram usadas como controles 503 amostras de crianças brasileiras, participantes do mesmo projeto, em quem não foi detectada nenhuma doença psiquiátrica. As amostras foram genotipadas em HumanCore-12 v1.0 BeadChip (Illumina, Inc.), com 298.930 SNPs. Foi usado o programa PennCNV (Wang, Li et al. 2007) para detectar variações no número de cópias (ou CNVs, do inglês copy-number variants).

\subsection{2 - Variações de número de cópias nos exomas de trios brasileiros}

Foi utilizado o programa XHMM (Fromer and Purcell 2014) para encontrar regiões no exoma com CNVs, sejam elas com deleções ou duplicações. Os CNVs foram filtrados para a remoção de falsos positivos. Foram removidos CNVs com qualidade/probabilidade (escala phred, que varia de 1 a 99) de ocorrência de algum evento de CNV no intervalo e a qualidade/probabilidade de a região não ser diploide com valor abaixo de 90 . Também foram removidos CNVs encontrados em mais que três pais (que são saudáveis), deleções cuja frequência de heterozigotos estava acima de $10 \%$, e duplicações com razão de alelos alternativos sobre alelos referência entre 0,4 e 0,6. Quaisquer $\mathrm{CNVs}$ que foram encontrados nas amostras de 503 crianças brasileiras saudáveis também foram removidos.

\subsection{3 - Análise de funções biológicas, bandas citogenéticas e doenças associadas}

Para realizar as análises de hiper-representação de genes em conjuntos de termos, dois programa foram utilizados. Para a análise de termos da Gene Ontology (GO), doenças e bandas citogenéticas, foi utilizado o programa WebGestalt (Wang, Duncan et al. 2013). Para esse programa, os genes do genoma humano foram usados como referência, as correções foram feitas com o método de Benjamini e Hochberg (1995), e somente foram considerados os 10 primeiros termos de cada análise cujo $p$-valor ajustado era menor que 0,05. Para as análises de termos da Kyoto Encyclopedia of Genes and Genomes (KEGG), pelo fato de ter uma versão mais recente desse banco, o programa STRING (Szklarczyk, Franceschini et al. 2015) foi utilizado. Nesse programa, foi utilizado o método de correção de Bonferroni e também foram considerados significantes termos cujo $p$-valor ajustado foi menor que 0,05 . 


\section{Capítulo 6 - Resultados}

\section{1 - Análise dos exomas de trios brasileiros}

\subsection{1 - Sequenciamento e mapeamento dos exomas de trios brasileiros}

O sequenciamento produziu em média uma quantidade de 24 milhões de sequências por amostra com tamanho de $100 \mathrm{pb}$, resultando em 2,4G de bases sequenciadas por amostra. Foi observada, nas amostras, uma grande variação na cobertura dos indivíduos sequenciados. A média de cobertura foi de $45 \mathrm{x}$ e em média tivemos $50 \%$ dos alvos cobertos pelo menos $20 x$.

\subsection{2 - Análise de variantes de único nucleotídeo em exomas de trios brasileiros}

Após a chamada de variantes, foi usado o programa KING (Manichaikul, Mychaleckyj et al. 2010) para estimar relações de parentesco. Além de encontrar possíveis erros nas famílias, o programa pode mostrar amostras com alguma contaminação no sequenciamento. Cinco trios foram removidos porque tiveram pelo menos um fator de parentesco menor que 0,19 ou baixa qualidade em pelo menos uma amostra. Trinta trios permaneceram na análise. Nós procuramos nas crianças por três tipos de variantes de único nucleotídeo (ou SNVs, do inglês singlenucleotide variants) que podem estar contribuindo para a doença:

i. Variações de novo com impacto moderado a alto (missense, nonsense ou splice site): 26 variantes foram encontradas em 25 genes, e todos eles estão expressos no cérebro (Tabela 5). No gene VWDE foram encontradas duas variantes na mesma criança. Uma das bandas citogenéticas apresentou variantes em três crianças diferentes: 19q13.

ii. Variações heterozigotas muito raras de alto impacto (nonsense ou splice site): 134 variantes diferentes foram encontradas em 134 genes que são expressos no cérebro. Seis desses genes apresentaram a mesma variante em duas crianças diferentes: ACOXL, ANKRD42, CYFIP2, MSR1, NPSR1, OBSL1. Os outros 128 genes apresentaram somente uma variante. Cinco bandas citogenéticas apresentaram variantes em pelo menos quatro crianças: 3q13, 5q33, 11p15 e 19p13. A banda 19q13 apresentou variantes em 10 crianças diferentes. Mais detalhes podem ser encontrados na Tabela Suplementar 2.

iii. Variações homozigóticas raras de impacto moderado que eram heterozigóticas nos pais: 127 variações diferentes foram encontradas em 120 genes expressos no cérebro. Cinco genes apresentaram duas variantes em uma única criança: ACSM1, GIMAP6, ILDR1, MUC6, RGS12. O gene IFLTD1 apresentou três variantes na mesma criança e o gene DNAH3 apresentou a mesma variação em duas crianças diferentes. Os outros 113 genes apresentaram somente uma variação desse tipo. As bandas citogenéticas 1p36 e 19q13 apresentaram variantes em quatro crianças diferentes. Os outros resultados estão detalhados na Tabela Suplementar 3. 
Tabela 5. As $\mathbf{2 6}$ variantes de único nucleotídeo de novo encontradas nos dados de exoma dos trios brasileiros.

\begin{tabular}{|c|c|c|c|c|c|c|c|}
\hline cro & pos & rsID & banda & gene & impacto & família & frequência \\
\hline 1 & 2494330 & rs2234167 & $1 p 36.32$ & TNFRSF14 & $\begin{array}{l}\text { NON } \\
\text { SYNON. } \\
\text { CODING }\end{array}$ & NN2624 & comum \\
\hline 1 & 41296828 & rs34287852 & $1 p 34.2$ & KCNQ4 & $\begin{array}{l}\text { NON } \\
\text { SYNON. } \\
\text { CODING }\end{array}$ & NN2901 & comum \\
\hline 2 & 233537125 & rs11550699 & $2 q 37.1$ & EFHD1 & $\begin{array}{l}\text { NON } \\
\text { SYNON. } \\
\text { CODING }\end{array}$ & NN3752 & comum \\
\hline 3 & 193380726 & rs200412464 & $3 q 29$ & OPA1 & $\begin{array}{l}\text { NON } \\
\text { SYNON. } \\
\text { CODING }\end{array}$ & NN3506 & muito rara \\
\hline 4 & 169195114 & . & $4 q 32.3$ & DDX60 & $\begin{array}{l}\text { NON } \\
\text { SYNON. } \\
\text { CODING }\end{array}$ & NN3506 & nova \\
\hline 5 & 825280 & rs1809008 & $5 p 15.33$ & ZDHHC11 & $\begin{array}{l}\text { NON } \\
\text { SYNON. } \\
\text { CODING }\end{array}$ & NN1075 & comum \\
\hline 7 & 12409263 & rs17165906 & $7 p 21.3$ & VWDE & $\begin{array}{l}\text { NON } \\
\text { SYNON. } \\
\text { CODING }\end{array}$ & NN2624 & comum \\
\hline 7 & 12409327 & rs17165910 & $7 p 21.3$ & VWDE & $\begin{array}{l}\text { NON } \\
\text { SYNON. } \\
\text { CODING }\end{array}$ & NN2624 & comum \\
\hline 7 & 73969541 & rs2301895 & $7 q 11.23$ & GTF2IRD1 & $\begin{array}{l}\text { NON } \\
\text { SYNON. } \\
\text { CODING }\end{array}$ & $1659 \mathrm{~F}$ & comum \\
\hline 9 & 87338590 & . & $9 q 21.33$ & NTRK2 & $\begin{array}{l}\text { NON } \\
\text { SYNON. } \\
\text { CODING }\end{array}$ & NN3506 & nova \\
\hline 9 & 101831995 & rs10519 & $9 q 22.33$ & COL15A1 & $\begin{array}{l}\text { NON } \\
\text { SYNON. } \\
\text { CODING }\end{array}$ & $1013 \mathrm{~F}$ & comum \\
\hline 9 & 133577672 & . & $9 q 34.12$ & EXOSC2 & $\begin{array}{l}\text { NON } \\
\text { SYNON. } \\
\text { CODING }\end{array}$ & NN3506 & nova \\
\hline 9 & 139694569 & rs7859194 & $9 q 34.3$ & KIAA1984 & $\begin{array}{l}\text { NON } \\
\text { SYNON. } \\
\text { CODING }\end{array}$ & $1350 \mathrm{~F}$ & comum \\
\hline 13 & 52544805 & rs1801244 & $13 q 14.3$ & ATP7B & $\begin{array}{l}\text { NON } \\
\text { SYNON. } \\
\text { CODING }\end{array}$ & NN2624 & comum \\
\hline 14 & 20249176 & rs2815960 & $14 q 11.2$ & OR4M1 & $\begin{array}{l}\text { NON } \\
\text { SYNON. } \\
\text { CODING }\end{array}$ & $1802 \mathrm{~F}$ & comum \\
\hline 14 & 24629768 & . & $14 q 12$ & RNF31 & $\begin{array}{l}\text { NON } \\
\text { SYNON. } \\
\text { CODING }\end{array}$ & $1013 \mathrm{~F}$ & nova \\
\hline 14 & 25043951 & rs61737120 & $14 q 12$ & CTSG & $\begin{array}{l}\text { NON } \\
\text { SYNON. } \\
\text { CODING }\end{array}$ & $691 \mathrm{~F}$ & rara \\
\hline 14 & 102391577 & rs3742424 & $14 q 32.31$ & PPP2R5C & $\begin{array}{l}\text { NON } \\
\text { SYNON. } \\
\text { CODING }\end{array}$ & $1732 \mathrm{~F}$ & comum \\
\hline
\end{tabular}




\begin{tabular}{|l|l|l|l|l|l|l|l|}
\hline $\mathbf{1 5}$ & 90818469 & rs12595409 & $15 q 26.1$ & $\begin{array}{l}\text { NGRN } \\
\text { (dist:3026) } \\
\text { DQ582071 } \\
\text { (dist:18035) }\end{array}$ & $\begin{array}{l}\text { STOP } \\
\text { GAINED }\end{array}$ & NN3506 & comum \\
\hline $\mathbf{1 7}$ & 7329310 & $\cdot$ & $17 p 13.1$ & C17orf74 & $\begin{array}{l}\text { SPLICE } \\
\text { SITE } \\
\text { ACCEPT } \\
\text { OR }\end{array}$ & $1372 \mathrm{~F}$ & nova \\
\hline $\mathbf{1 7}$ & 11784614 & $\cdot$ & $17 p 12$ & DNAH9 & $\begin{array}{l}\text { NON } \\
\text { SYNON. } \\
\text { CODING }\end{array}$ & $1659 \mathrm{~F}$ & nova \\
\hline $\mathbf{1 8}$ & 61323012 & rs3180227 & $18 q 21.33$ & SERPINB3 & $\begin{array}{l}\text { NON } \\
\text { SYNON. } \\
\text { CODING }\end{array}$ & $894 \mathrm{~F}$ & comum \\
\hline $\mathbf{1 8}$ & 61570529 & rs6104 & $18 q 21.33$ & SERPINB2 & $\begin{array}{l}\text { NON } \\
\text { SYNON. } \\
\text { CODING }\end{array}$ & NN3506 & comum \\
\hline $\mathbf{1 9}$ & 5691424 & $\cdot$ & $19 p 13.3$ & RPL36 & $\begin{array}{l}\text { NON } \\
\text { SYNON. } \\
\text { CODING }\end{array}$ & NN3538 & nova \\
\hline $\mathbf{1 9}$ & 8191184 & rs35025963 & $19 p 13.2$ & FBN3 & $\begin{array}{l}\text { NON } \\
\text { SYNON. } \\
\text { CODING }\end{array}$ & NN1075 & comum \\
\hline $\mathbf{1 9}$ & 17660300 & rs11666267 & $19 p 13.11$ & FAM129C & $\begin{array}{l}\text { NON } \\
\text { SYNON. } \\
\text { CODING }\end{array}$ & $1659 F$ & comum \\
\hline
\end{tabular}

\subsection{3 - Análise de variação de número de cópias em exomas de trios brasileiros}

Após mapear as sequências no genoma (GRCh37/hg19), usamos o programa XHMM (Fromer and Purcell 2014) para buscar variações de número de cópias (ou CNVs, do inglês copy-number variation). Foram encontradas 13 ocorrências de CNVs putativos em crianças brasileiras, sendo três de novo, sete herdadas do pai e três herdadas da mãe. Nessas regiões, 22 genes foram encontrados expressos no cérebro. A Tabela Suplementar 1 mostra todos os CNVs encontrados nos 30 trios. O gene TRIM48 (11q11) foi encontrado em um CNV herdado e um CNV de novo em duas crianças diferentes. Usamos a ferramenta BEDTools (Quinlan 2014) para encontrar as interseções de CNVs e descobrir quais eram herdados ou de novo.

\subsection{4 - Análise combinadas de SNVs e CNVs em trios brasileiros}

Para investigar como variantes herdadas e de novo estavam distribuídas em crianças brasileiras, nós juntamos SNVs e CNVs herdados e comparamos com SNVs e CNVs de novo em grupos separados. Isso é mostrado na Figura 4. Ao calcularmos as quantidades de comorbidades dos grupos de crianças com e sem variações de novo, obtivemos os seguintes valores: crianças com alguma variação de novo tiveram em média 0,36 comorbidades, e crianças sem nenhuma variação de novo tiveram em média 0,88 comorbidades. Os conjuntos são diferentes, de acordo com o teste $t$ aplicado ( $p$-valor $=0,02979$ ). Estes dados estão mais detalhados nas Tabelas Suplementares 4 e 5. 


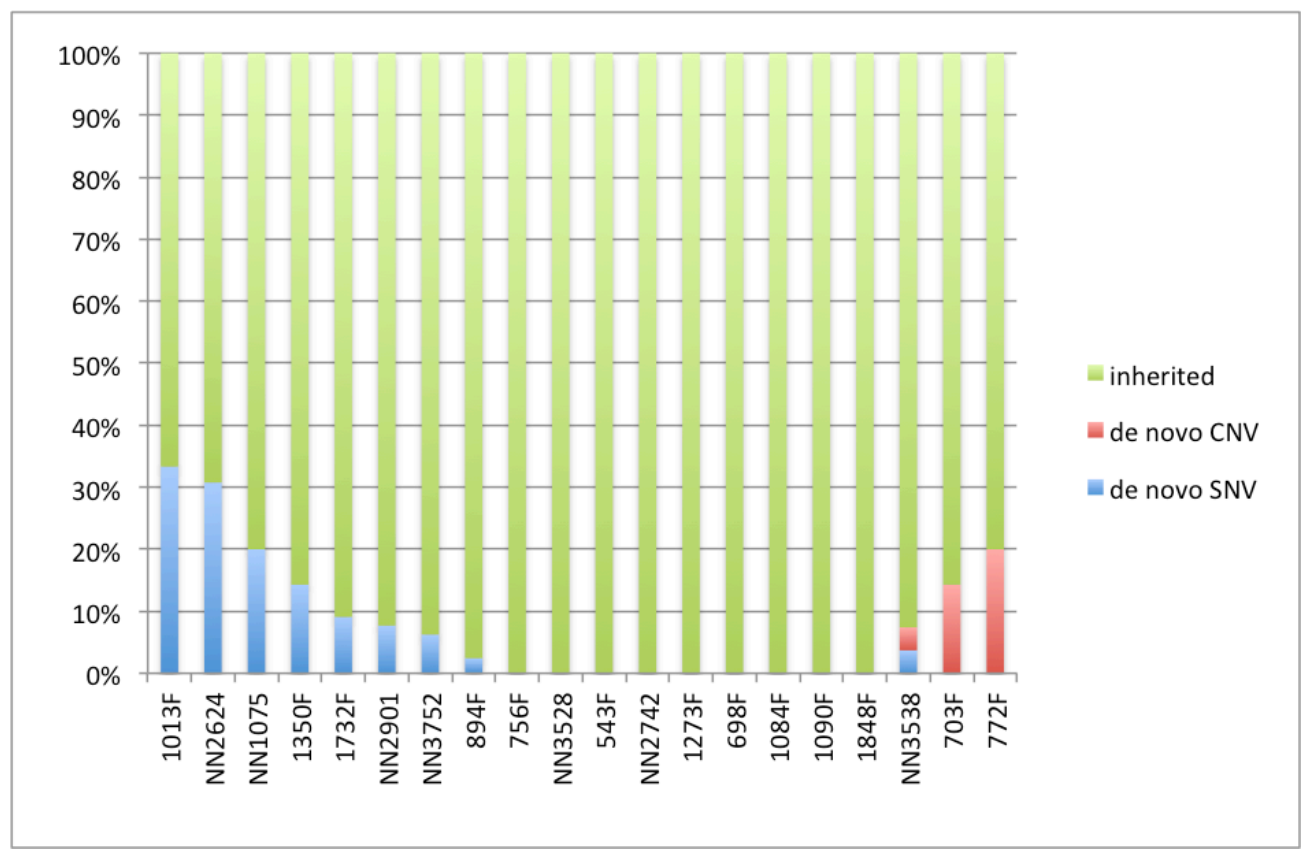

Figura 4. Gráfico de barras com as percentagens de variantes herdadas e de novo (separadas em CNVs e SNVs) em crianças brasileiras na análise de exoma.

\section{2 - Análise funcional integrada de genes em SNPs, SNVs ou CNVs}

Foi feita a análise funcional de todos os genes com ocorrência na análise incluída neste trabalho, ou seja, em CNV ou com SNP em bancos de dados públicos e genes em CNVs ou com SNVs no exoma de crianças brasileiras. No total, o conjunto final foi de 1128 genes expressos em cérebro. Nós removemos os receptores olfatórios (80 genes) para evitar viés na análise funcional. Após isso, o conjunto final ficou com 1048 genes.

A análise de categorias da Gene Ontology (GO) desses genes mostrou resultados significantes para a função molecular "ligand-gated ion channel activity" (GO:0015276), com 18 genes e p-valor ajustado de 0,0093. A análise de termos do KEGG mostrou resultados significantes para "Neuroactive ligand-receptor interaction" (22 genes, p-valor ajustado = 9,63e-05), "Metabolic pathways" (50 genes, $p$-valor ajustado $=0,0015)$, "Calcium signaling pathway" (14 genes, $p$-valor ajustado $=0,0025)$, "Tight junction" (12 genes, p-valor ajustado $=0,0025)$, "Ubiquitin mediated proteolysis" (12 genes, p-valor ajustado $=0,0025)$, "Adherens junction" (8 genes, $p$-valor ajustado $=0,0056)$, "Cytokine-cytokine receptor interaction" (15 genes, $p$-valor ajustado $=0,0238)$. As bandas citogenéticas significantemente associadas com TDAH foram $15 \mathrm{q} 11$ (88 genes, $\mathrm{p}$-valor ajustado $=1,30 \mathrm{e}-87$ ), $16 \mathrm{p} 11$ (70 genes, p-valor ajustado $=6,82 \mathrm{e}-55), 7 \mathrm{p} 15$ (20 genes, $\mathrm{p}$-valor ajustado $=8,26 \mathrm{e}-$ 12), 11q25 (10 genes, $p$-valor ajustado $=3,86 \mathrm{e}-08), 4 \mathrm{p} 15$ (15 genes, $p$-valor ajustado $=6,02 \mathrm{e}-08), 15 \mathrm{q} 12(20$ genes, $\mathrm{p}$-valor ajustado $=2,69 \mathrm{e}-07), 20 \mathrm{p} 13(15$ genes, $p$-valor ajustado $=3,22 \mathrm{e}-07$ ) e $8 \mathrm{q} 21$ (16 genes, $\mathrm{p}$-valor ajustado $=4,08 \mathrm{e}-07$ )

\section{3 - Redes de interação proteína-proteína}

A lista total de transcritos expressos no cérebro contem um conjunto de 54141. Usando somente esse sub-conjunto de transcritos expressos em cérebro, obtivemos 
12464 transcritos ao buscarmos as interações proteína-proteína em humanos, no banco iReflndex, com pelo menos duas fontes de confirmação. Para estudar como os genes estão relativamente localizados no espaço da rede, nós criamos uma rede com a lista de genes relacionados a TDAH e suas interações diretas usando para isso informações de bancos de dados de interação proteína-proteína (ou PPI, do inglês protein-protein interaction). Esta rede é composta apenas de genes expressos no cérebro. Dos 1128 genes iniciais, somente 557 estavam presentes nos bancos de dados PPI. Além destes, mais 2240 genes foram adicionados a essa rede, que é mostrada na Figura 5.

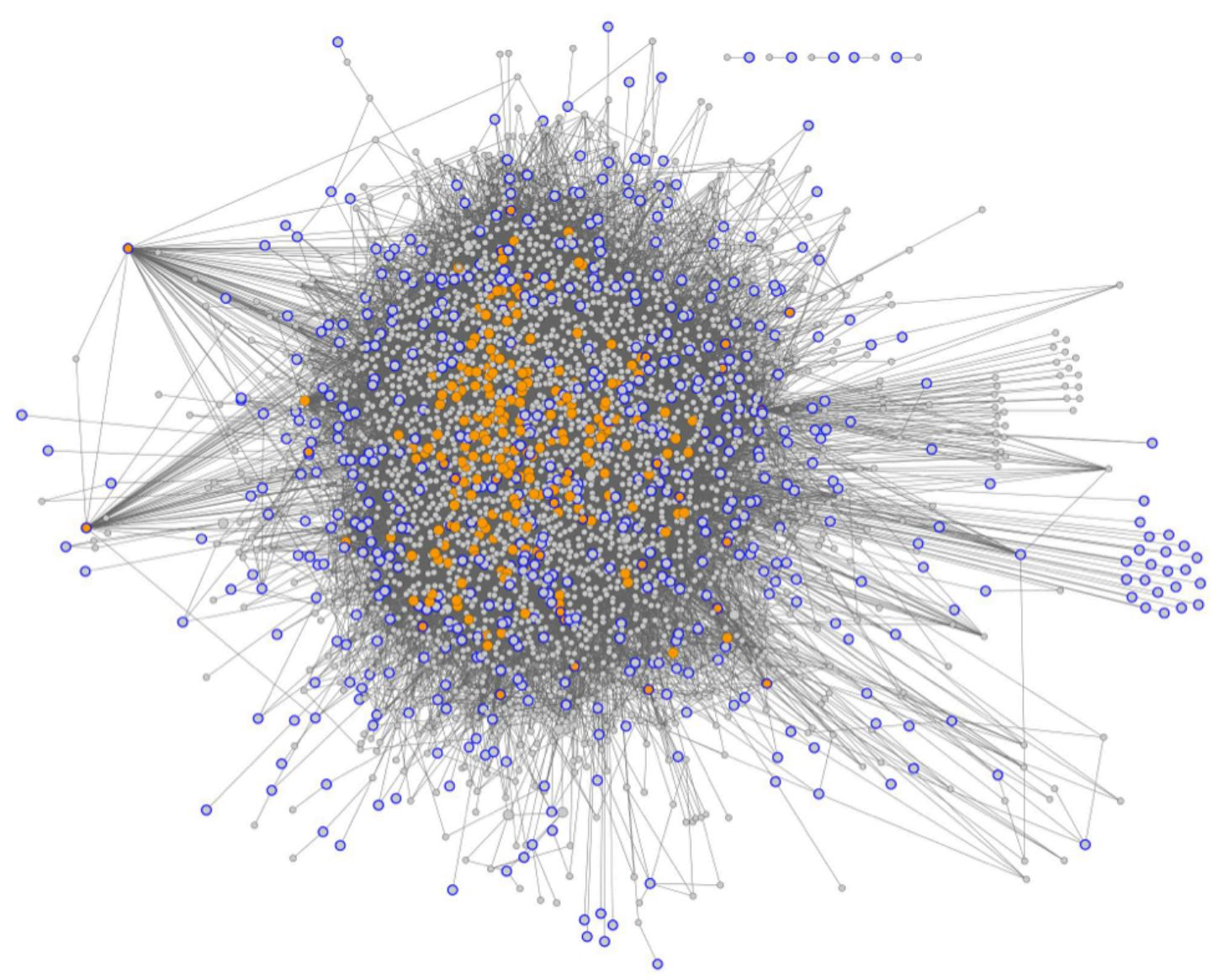

Figura 5. Rede criada com os genes utilizados nas análises deste trabalho (com borda azul) e suas interações, de acordo com bancos de dados de interação proteína-proteína. Os genes em laranja são nós corretores ou gargalos. Somente $5,5 \%$ dos genes iniciais são centrais (corretores ou gargalos).

Para termos uma análise mais específica de genes com SNVs ou em CNVs, nós selecionamos genes com ocorrências em pelo menos duas análises, com mais de uma variante na mesma criança ou duas variantes em crianças diferentes. Esse conjunto ficou com 30 genes, que são mostrados na Tabela 6.

Tabela 6. Genes com pelo menos duas ocorrências em categorias diferentes de análise, com ocorrência em crianças diferentes ou com mais de uma variante na mesma criança. Legenda: mv2c: mesma variante em duas crianças diferentes; $2 \mathrm{vmc}$ : duas variantes na mesma criança. Células em que foram encontradas variantes no gene para a análise da coluna correspondente estão em cinza.

\begin{tabular}{|l|l|l|l|l|l|l|}
\hline gene & $\begin{array}{l}\text { CNVs } \\
\text { públicos }\end{array}$ & $\begin{array}{l}\text { SNPs } \\
\text { públicos }\end{array}$ & $\begin{array}{l}\text { CNVs no } \\
\text { exoma }\end{array}$ & $\begin{array}{l}\text { SNVs no } \\
\text { exoma }\end{array}$ & banda & referência \\
\hline ACOXL (acyl-CoA & não & não & não & mv2c & $2 q 13$ & (Roberts, Hovanes \\
\hline
\end{tabular}




\begin{tabular}{|c|c|c|c|c|c|c|}
\hline oxidase-like) & & & & & & et al. 2014) \\
\hline $\begin{array}{l}\text { ACSM1 (acyl-CoA } \\
\text { synthetase } \\
\text { medium-chain } \\
\text { family member 1) }\end{array}$ & não & não & não & $2 \mathrm{vmc}$ & $16 p 12.3$ & (Li, Ji et al. 2015) \\
\hline $\begin{array}{l}\text { ANKRD42 (ankyrin } \\
\text { repeat domain 42) }\end{array}$ & não & não & não & $\mathrm{mv} 2 \mathrm{c}$ & $11 q 14.1$ & \\
\hline $\begin{array}{l}\text { CNGB3 (cyclic } \\
\text { nucleotide gated } \\
\text { channel beta } 3 \text { ) }\end{array}$ & $\operatorname{sim}$ & não & não & $\operatorname{sim}$ & $8 q 21.3$ & \\
\hline $\begin{array}{l}\text { CYFIP2 } \\
\text { (cytoplasmic FMR1 } \\
\text { interacting protein } \\
\text { 2) }\end{array}$ & não & não & não & $\mathrm{mv} 2 \mathrm{c}$ & $5 q 33.3$ & $\begin{array}{l}\text { (Focking, Lopez et } \\
\text { al. 2015) }\end{array}$ \\
\hline $\begin{array}{l}\text { CYP19A1 } \\
\text { (cytochrome P450, } \\
\text { family 19, subfamily } \\
\text { A, polypeptide 1) }\end{array}$ & $\operatorname{sim}$ & não & não & $\operatorname{sim}$ & $15 q 21.2$ & \\
\hline $\begin{array}{l}\text { DDX60 (DEAD } \\
\text { (Asp-Glu-Ala-Asp) } \\
\text { box polypeptide 60) }\end{array}$ & $\operatorname{sim}$ & não & não & $\operatorname{sim}$ & $4 q 32.3$ & \\
\hline $\begin{array}{l}\text { DNAH3 (dynein, } \\
\text { axonemal, heavy } \\
\text { chain 3) }\end{array}$ & não & não & não & $\mathrm{mv} 2 \mathrm{c}$ & $16 \mathrm{p} 12.3$ & \\
\hline $\begin{array}{l}\text { DNHD1 (dynein } \\
\text { heavy chain domain } \\
\text { 1) }\end{array}$ & $\operatorname{sim}$ & não & não & $\operatorname{sim}$ & $11 \mathrm{p} 15.4$ & \\
\hline $\begin{array}{l}\text { EMP2 (epithelial } \\
\text { membrane protein } \\
\text { 2) }\end{array}$ & $\operatorname{sim}$ & $\operatorname{sim}$ & não & não & $16 p 13.13$ & $\begin{array}{l}\text { (Ghani, Sato et al. } \\
\text { 2013) }\end{array}$ \\
\hline $\begin{array}{l}\text { GIMAP6 (GTPase, } \\
\text { IMAP family } \\
\text { member 6) }\end{array}$ & não & não & não & $2 \mathrm{vmc}$ & $7 q 36.1$ & \\
\hline $\begin{array}{l}\text { GOLGA8DP (golgin } \\
\text { A8 family, member } \\
D, \text { pseudogene) }\end{array}$ & $\operatorname{sim}$ & não & $\operatorname{sim}$ & não & $15 q 11.2$ & \\
\hline $\begin{array}{l}\text { HEATR1 (HEAT } \\
\text { repeat containing 1) }\end{array}$ & $\operatorname{sim}$ & não & não & $\operatorname{sim}$ & $1 q 43$ & \\
\hline $\begin{array}{l}\text { IFLTD1 (lamin tail } \\
\text { domain containing } \\
\text { 1) }\end{array}$ & não & não & não & $3 \mathrm{vmc}$ & $12 \mathrm{p} 12.1$ & \\
\hline $\begin{array}{l}\text { ILDR1 } \\
\text { (immunoglobulin- } \\
\text { like domain } \\
\text { containing receptor } \\
\text { 1) }\end{array}$ & não & não & não & $2 \mathrm{vmc}$ & $3 q 13.33$ & \\
\hline $\begin{array}{l}\text { ITGA3 (integrin, } \\
\text { alpha } 3 \text { (antigen } \\
\text { CD49C, alpha } 3 \\
\text { subunit of VLA-3 } \\
\text { receptor)) }\end{array}$ & $\operatorname{sim}$ & não & não & $\operatorname{sim}$ & $17 q 21.33$ & \\
\hline $\begin{array}{l}\text { MSR1 } \\
\text { (macrophage } \\
\text { scavenger receptor } \\
\text { 1) }\end{array}$ & não & não & não & $\mathrm{mv} 2 \mathrm{c}$ & $8 p 22$ & \\
\hline $\begin{array}{l}\text { MUC6 (mucin 6, } \\
\text { oligomeric } \\
\text { mucus/gel-forming) }\end{array}$ & não & não & não & $2 \mathrm{vmc}$ & $11 \mathrm{p} 15.5$ & \\
\hline $\begin{array}{l}\text { NPSR1 } \\
\text { (neuropeptide S } \\
\text { receptor 1) }\end{array}$ & não & não & não & $\mathrm{mv} 2 \mathrm{c}$ & $7 p 14.3$ & \\
\hline $\begin{array}{l}\text { OBSL1 (obscurin- } \\
\text { like 1) }\end{array}$ & não & não & não & $\mathrm{mv} 2 \mathrm{c}$ & $2 q 35$ & \\
\hline $\begin{array}{l}\text { OR8K3 (olfactory } \\
\text { receptor, family } 8 \text {, }\end{array}$ & $\operatorname{sim}$ & não & não & $\operatorname{sim}$ & $11 q 12.1$ & \\
\hline
\end{tabular}




\begin{tabular}{|c|c|c|c|c|c|c|}
\hline $\begin{array}{l}\text { subfamily K, } \\
\text { member 3) }\end{array}$ & & & & & & \\
\hline $\begin{array}{l}\text { PPP6R3 (protein } \\
\text { phosphatase } 6, \\
\text { regulatory subunit } \\
\text { 3) }\end{array}$ & $\operatorname{sim}$ & não & não & $\operatorname{sim}$ & 11q13.2 & \\
\hline $\begin{array}{l}\text { RGS12 (regulator } \\
\text { of G-protein } \\
\text { signaling 12) }\end{array}$ & não & não & não & $2 \mathrm{vmc}$ & $4 \mathrm{p} 16.3$ & $\begin{array}{l}\text { (Guipponi, Santoni } \\
\text { et al. 2014) }\end{array}$ \\
\hline $\begin{array}{l}\text { SDK1 (sidekick cell } \\
\text { adhesion molecule } \\
\text { 1) }\end{array}$ & $\operatorname{sim}$ & não & não & $\operatorname{sim}$ & $7 p 22.2$ & \\
\hline $\begin{array}{l}\text { SMYD3 (SET and } \\
\text { MYND domain } \\
\text { containing 3) }\end{array}$ & $\operatorname{sim}$ & não & não & $\operatorname{sim}$ & $1 q 44$ & \\
\hline $\begin{array}{l}\text { TRIM22 (tripartite } \\
\text { motif containing 22) }\end{array}$ & $\operatorname{sim}$ & não & não & $\operatorname{sim}$ & $11 \mathrm{p} 15.4$ & \\
\hline $\begin{array}{l}\text { TRIM48 (tripartite } \\
\text { motif containing 48) }\end{array}$ & não & não & $\mathrm{mv} 2 \mathrm{c}$ & não & $11 q 11$ & \\
\hline $\begin{array}{l}\text { TRIML2 (tripartite } \\
\text { motif family-like } \\
\text { 2) }\end{array}$ & $\operatorname{sim}$ & não & não & $\operatorname{sim}$ & $4 q 35.2$ & \\
\hline $\begin{array}{l}\text { UQCRC2 } \\
\text { (ubiquinol- } \\
\text { cytochrome c } \\
\text { reductase core } \\
\text { protein II) }\end{array}$ & $\operatorname{sim}$ & não & não & $\operatorname{sim}$ & $16 p 12.2$ & $\begin{array}{l}\text { (dela Pena, Kim et } \\
\text { al. 2014) }\end{array}$ \\
\hline $\begin{array}{l}\text { VWDE (von } \\
\text { Willebrand factor } \\
\text { D and EGF } \\
\text { domains) }\end{array}$ & não & não & não & $2 \mathrm{vmc}$ & $7 p 21.3$ & \\
\hline
\end{tabular}

Usando somente estes 30 genes como sementes, construímos uma sub-rede também adicionando as interações diretas para analisar quais funções biológicas estão associadas a esses genes. Dos 30 genes, apenas 15 estavam nos bancos de dados de PPI. A rede final ficou com 101 genes (Figura 6). Usando o programa WebGestalt, encontramos funções biológicas e módulos proteicos hiperrepresentados nos genes dessa rede. Com relação a componentes celulares (do banco GO), há 13 genes relacionados a "neural projection" ( $p$-valor ajustado = $6,00 \mathrm{e}-04), 5$ genes relacionados a "cell-substrate adherens junction" ( $p$-valor ajustado $=3,00 \mathrm{e}-03$ ), 34 genes relacionados a "membrane-enclosed lumen" ( $p$-valor ajustado $=1,60 \mathrm{e}-03$ ) e 14 genes relacionados a "synapse" ( $p$-valor ajustado $=7,80 \mathrm{e}$ 05). Usando o programa STRING, foi feita a análise de enriquecimento de vias para o KEGG e foram obtidos resultados mais específicos para genes de sinapse, através dos termos "glutamatergic synapse" (7 genes, p-valor ajustado $=3,28 \mathrm{e}-04)$ e "serotoninergic synapse" (6 genes, p-valor ajustado $=4,81 \mathrm{e}-03$ ). Os demais termos encontram-se descrito na Tabela 7. Além disso, os genes relacionados a sistema nervoso central (termo "central nervous system") estão significativamente conectados na rede, de acordo com a análise de módulos proteicos do programa WebGestalt ( $p$-valor ajustado $=3,02 e-05$ ). 


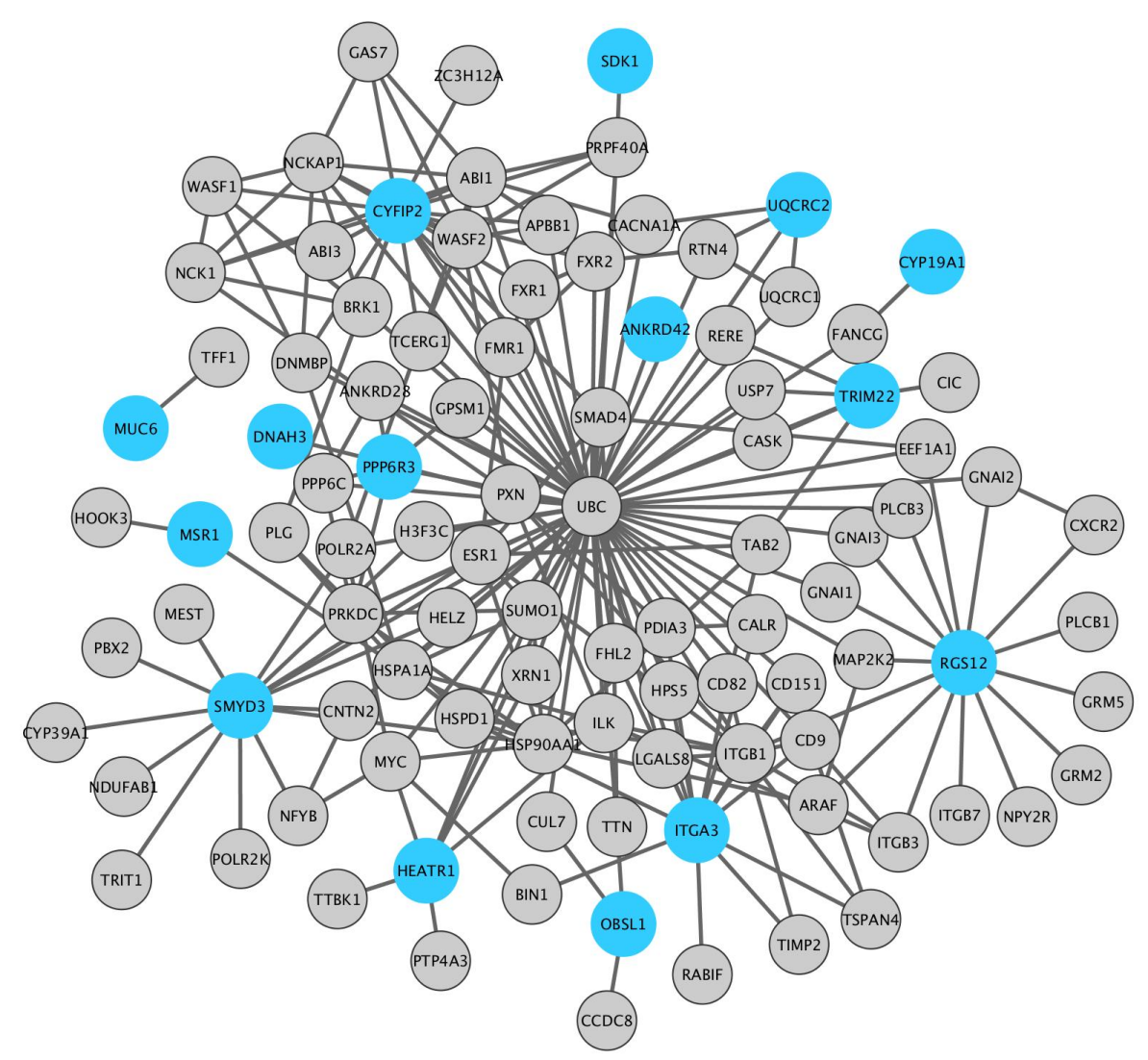

Figura 6. Rede com genes em pelo menos duas ocorrências nas análises deste trabalho (que são as sementes, em azul) e suas interações diretas (nós cinza) em bancos de dados de interação proteína-proteína.

Tabela 7. Termos de KEGG dos genes na sub-rede com p-valor significante após a correção de Bonferroni pelo programa STRING.

\begin{tabular}{|r|l|r|r|r|}
\hline \multicolumn{1}{|c|}{ GO } & \multicolumn{1}{|c|}{ Termo } & $\begin{array}{r}\text { no. de } \\
\text { genes }\end{array}$ & p-valor & \multicolumn{1}{|c|}{$\begin{array}{c}\text { p-valor } \\
\text { Bonferroni }\end{array}$} \\
\hline 4810 & Regulation of actin cytoskeleton & 11 & $6.59 \mathrm{E}-09$ & $1.89 \mathrm{E}-06$ \\
\hline 4730 & Long-term depression & 7 & $1.42 \mathrm{E}-08$ & $4.07 \mathrm{E}-06$ \\
\hline 4915 & Estrogen signaling pathway & 8 & $1.92 \mathrm{E}-08$ & $5.51 \mathrm{E}-06$ \\
\hline 5016 & Huntington's disease & 9 & $2.83 \mathrm{E}-07$ & $8.11 \mathrm{E}-05$ \\
\hline 4724 & Glutamatergic synapse & 7 & $1.14 \mathrm{E}-06$ & $3.28 \mathrm{E}-04$ \\
\hline 4540 & Gap junction & 6 & $3.46 \mathrm{E}-06$ & $9.93 \mathrm{E}-04$ \\
\hline 4723 & Retrograde endocannabinoid signaling & 6 & $8.07 \mathrm{E}-06$ & $2.32 \mathrm{E}-03$ \\
\hline 4720 & Long-term potentiation & 5 & $1.49 \mathrm{E}-05$ & $4.27 \mathrm{E}-03$ \\
\hline 4726 & Serotonergic synapse & 6 & $1.67 \mathrm{E}-05$ & $4.81 \mathrm{E}-03$ \\
\hline
\end{tabular}




\section{Capítulo 7 - Discussão}

$\mathrm{Na}$ literatura, tem sido bastante difícil alcançar resultados significantes em estudos genéticos de transtorno de déficit de atenção e hiperatividade (TDAH), mesmo com a herdabilidade sendo estimada em 70 a $80 \%$ (Faraone, Perlis et al. 2005). Plataformas de polimorfismos de único nucleotídeo (SNPs) têm sido usadas em estudos de associação ao longo do genoma (GWAS) e variação em número de cópias (CNVs) em TDAH tem contribuído com a ideia de que TDAH compartilha variantes com outras doenças neuropsiquiátricas. Genes relacionados à origem de sinapse e canais de cálcio têm sido descritos como muito importantes (Archer, Oscar-Berman et al. 2011, Stanford 2014, Ohgi, Futamura et al. 2015). Alguns genes parecem ser mais relacionados a suscetibilidade de qualquer doença psiquiátrica, mas a combinação de variações não-específicas com variações específicas podem trazer mais luz a uma doença em particular (Cross-Disorder Group of the Psychiatric Genomics Consortium 2013, Serretti and Fabbri 2013). Seguindo esta ideia, nós exploramos diferentes variantes em TDAH usando dados de exoma de trios brasileiros. Um método intuitivo de encontrar variações relacionas à doença é buscar por variações de novo em trios cujos pais são saudáveis e a criança tem a doença. Tais mutações têm sido mostradas como potenciais causas de várias doenças psiquiátricas (Sebat, Lakshmi et al. 2007, Vissers, de Ligt et al. 2010, Girirajan, Brkanac et al. 2011, Xu, Roos et al. 2011, Neale, Kou et al. 2012, Veltman and Brunner 2012, Krumm, O'Roak et al. 2013, Fromer, Pocklington et al. 2014, McLysaght, Makino et al. 2014). Usando esta abordagem, nós encontramos 26 SNVs de novo com impacto moderado a alto em 25 genes expressos em cérebro em 14 crianças diferentes e três CNVs de novo em diferentes crianças.

No entanto, também foi mostrado que variantes raras ou herdadas (Poultney, Goldberg et al. 2013) desempenham um papel importante em outras doenças do neurodesenvolvimento (Girirajan and Eichler 2010). Assumindo que isso não seria diferente com TDAH, pois também é uma doença do neurodesenvolvimento, incluímos nesse trabalho CNVs e SNVs herdados. Com relação aos resultados de SNVs, encontramos 127 variantes raras, homozigotas, de impacto moderado (missense) para loci em que ambos os pais eram heterozigotos, em 120 genes expressos no cérebro, sugerindo uma possível herdabilidade recessiva como foi mostrado para autismo (Yu, Chahrour et al. 2013). Além disso, 134 variantes heterozigotas, muito raras, de alto impacto (nonsense e splice site) foram encontradas em 134 genes expressos no cérebro. Em relação a variantes estruturais, foram encontrados $10 \mathrm{CNVs}$ herdados que não estavam presentes em crianças e adolescentes saudáveis brasileiros. Embora tenhamos encontrado CNVs herdados mais do pai (em sete crianças) que da mãe (em três crianças), a limitação do tamanho de nossa amostra torna difícil afirmar que esse é uma padrão recorrente.

No presente estudo, em adição ao problema do tamanho amostral, há também o problema da miscigenação populacional (brasileira), que traz algumas particularidades à análise (Ruiz-Linares, Adhikari et al. 2014). Além disso, há a limitação relacionada à combinação de dados do mesmo tipo gerado por técnicas 
diferentes. Embora combinar estudos de exoma e GWAS traga algumas limitações técnicas, alguns trabalhos têm sido publicados com abordagens para unir ambos os métodos (O'Connell and Marchini 2012, Glessner, Bick et al. 2014, Hu, Li et al. 2015). Dessa forma, optamos em combinar estudos de exoma com estudo de GWAS para podermos ter como controles crianças brasileiras controles e não apenas bancos de dados de não brasileiros. É importante notar que nós comparamos neste trabalho CNVs encontrados em crianças brasileiras com TDAH usando dados de exoma com CNVs encontrados em 503 crianças brasileiras sem TDAH usando lâminas de array de SNPs para que fossem removidos quaisquer CNV presentes em dados controle.

Em relação a variantes encontradas nos exomas de amostras brasileiras, pudemos observar que houve a predominância de variações herdadas em comparação as variantes de novo, nos probandos. Todos os probandos apresentaram diferentes variações herdadas, mas nem todos apresentaram variações de novo. Além disso, parece haver um balanço entre variações de novo: crianças que apresentaram SNVs de novo não apresentaram CNVs de novo, e viceversa (há somente uma exceção, que é uma criança com um CNV de novo e um SNV de novo). Em recentes estudos sobre a arquitetura genética de outras doenças psiquiátricas (Girirajan and Eichler 2010), como autismo (Wang, Zhang et al. 2009, State and Levitt 2011, Devlin and Scherer 2012), esquizofrenia (Rodriguez-Murillo, Gogos et al. 2012, Schizophrenia Working Group of the Psychiatric Genomics Consortium 2014), e transtorno bipolar (Kerner 2014), tem sido mostrada a contribuição de variações de novo e herdadas, assim como de variações comuns e raras. Particularmente em TDAH, Yang e colegas (2013) realizaram uma análise caso-controle usando dados de array (Affymetrix 6.0) de uma coorte grande de indivíduos chineses com o objetivo de descobrir tanto variações raras quanto comuns relacionadas a TDAH. Embora eles não tenham encontrado resultados significantes em nível genômico, eles conseguiram indicar algumas vias biológicas usando análise de redes integrando genes com associação mais forte. Mais recentemente, Martin e colegas (2015) usaram amostras de crianças do reino unido para testar se as que tinham TDAH com CNVs grandes raros tinham risco poligênico (baseado em SNPs) diferente para a doença quando comparadas a crianças com TDAH porém sem tais CNVs. Em outras palavras, os resultados implicaram que crianças com CNVs grandes e raros precisam de menos SNPs para desenvolver a doença do que crianças que não tenham esses CNVs. No entanto, como os dados de exoma possibilitaram olhar também para CNVs menores que 100 mil bases (100kb), estes foram incluídos em nossas análises, pois também poderiam estar contribuindo para a doença.

Quando combinamos CNVs e SNVs levando em conta variantes encontradas em nossa análises e em dados públicos, pudemos ver resultados interessantes quanto a funções biológicas e outras doenças significativamente associados a genes de TDAH. Por exemplo, há termos de GO para função molecular e termos KEGG que estão relacionados à atividade celular no cérebro, como "ligand-gated ion channel activity", função cujos genes têm sido estudados como alvos terapêuticos de TDAH, doença de Alzheimer, esquizofrenia, depressão e vício em tabaco (Taly, Corringer et al. 2009). Outras vias encontradas inclusive já foram relacionados a 
TDAH, ou contêm genes relacionados a TDAH: "Neuroactive ligand-receptor interaction" (o banco ADHDgene mostra 89 genes), "Calcium signaling pathway" (66 genes no banco ADHDgene) e "Cytokine-cytokine receptor interaction" (Neale, Lasky-Su et al. 2008, Zhang, Chang et al. 2012). Apesar de algumas das bandas citogenéticas hiperrepresentadas nas nossas análises de rede já terem sido descritas como relacionadas a TDAH, mas somente a região 11q25 está entre as principais do banco ADHDgene, sugerindo que nossa análise de redes poderia estar contribuindo para a associação de novas regiões genômicas à doença.

Cai e colegas (2010) mostraram que, em redes de interação proteínaproteína, genes relacionados a doenças tendem a serem nós-corretores, e essa propriedade se mantém robusta mesmo com o viés do interatoma. Outros estudos mostraram que propriedades de genes na rede são diferentes, caso estes estejam ou não relacionados a doenças, mesmo se estão relacionados a diferentes tipos de variação genética (Barabasi, Gulbahce et al. 2011, Goh and Choi 2012). É interessante observar que na rede criada usando-se como sementes todos os genes envolvidos com alguma variação ( $S N V$ ou CNV) em TDAH, tais genes não são centrais ou fortemente conectados. Embora tenham sido usadas para dar início à rede, as sementes acabam ficando na periferia. Isso reforça que, tais variantes, separadamente, não são severas. Ao contrário, é necessária a combinação de fatores que engatilham o surgimento da doença. Juntamente com outras interações, os genes com SNVs ou em CNVs formaram na rede módulos de genes relacionados a importantes funções biológicas.

Resultados promissores surgiram quando somente genes recorrentes com pelo menos duas variações, seja em crianças, loci ou análises diferentes, foram usados como sementes para a construção de uma rede mais restrita. Isso foi feito porque tais genes, por terem mais de uma variação confirmando a relação com a doença, são mais confiáveis para a análise. Primeiramente, escolhemos cuidadosamente tais genes verificando quais eram recorrentes em: (i) diferentes análises, seja de dados públicos ou do exoma de crianças brasileiras, (ii) diferentes loci, mesmo que na mesma criança, ou (iii) diferentes loci em crianças diferentes. Depois disso, adicionamos as interações diretas de tais genes na rede também utilizando o critério de usar interações com pelo menos duas análises que confirmem a ligação em estudos de PPI. Ao analisarmos as vias hiperrepresentadas, encontramos genes significativamente relacionados a sinapse glutamatérgica, bem como sinapse serotoninérgica. Em um estudo de 2012, Elia e colegas mostraram redes com genes associados a neurotransmissão glutamatérgica que estavam afetados por CNVs de múltiplos coortes de pacientes com TDAH. Esses achados foi replicados por Akutagava-Martins e colegas (2014) em amostras brasileiras, confirmando o papel do glutamato em TDAH.

Também foi importante notar que a interação entre os genes CYFIP2 (Cytoplasmic FMR1-interacting protein 2) e FMRP (fragile $X$ mental retardation 1) foi confirmada em nossa rede. Importantemente, o CYFIP2 é um componente do complexo regulatório WAVE, um regulador importante do citoesqueleto. Han e colaboradores (2015) mostraram que o CYFIP2 estaria envolvido na regulação das espinhas dendríticas em neurônios do córtex cerebral, que é uma área do cérebro que desempenha um papel fundamental na atenção, percepção, memória e 
pensamento. Alguns dos genes sementes já foram associados a outras doenças do neurodesenvolvimento, tais como esquizofrenia, por exemplo o gene ACSM1 ( $\mathrm{Li}, \mathrm{Ji}$ et al. 2015) e autismo, com o gene CYP19A1 (Crider, Thakkar et al. 2014). Interessantemente, os genes NPSR1 e UQCRC2 parecem ser mais específicos de TDAH. O gene NPSR1 é modulado por vias sinalizadoras de cálcio e está envolvido com a modulação do funcionamento pré-frontal em sistemas de atenção e deficiências motoras (Erdmann, Kugler et al. 2015, Neufang, Geiger et al. 2015) e o gene UQCRC2 têm sido associado ao tratamento com metilfenidato (dela Pena, Kim et al. 2014).

Yang e colaboradores (2013) também combinaram CNVs e SNPs para estudar a genética do TDAH. O trabalho deles, que usou redes para investigar o papel de diferentes tipos de variantes, relatou que as funções de GO "sinapse" (com 15 genes) e "projeção neural" (com 16 genes) estavam associadas a regiões regulatórias. Interessantemente, embora tenhamos confirmado essas categorias, a interseção de genes foi baixa - somente o gene CNTN2 está em ambas as categorias. Com relação aos genes da via glutamatérgica, com nossa abordagem também foi possível encontrar genes que não haviam sido relatados anteriormente em TDAH: PLCB1, PLCB3, GNAI2, GNAI3 e CACNA1A. Embora esses resultados confirmem que a ruptura nestas vias está associada à doença em questão, isso também confirma a complexidade e heterogeneidade da doença, mostrando que em diferentes pacientes, famílias ou populações, variações envolvendo outros genes podem estar conduzindo ao desenvolvimento da doença.

\section{Resumo das contribuições do doutorado}

Usando uma técnica inovadora de integração de dados públicos com dados dos primeiros exomas gerados para probandos com TDAH esporádico, encontramos outros genes relacionados a vias biológicas já relacionadas à mesma doença na literatura. Embora nossos resultados confirmem achados publicados por outros grupos de pesquisa, mais análises são essenciais para confirmar as hipóteses e vias biológicas em amostras maiores. Nossas análises exclusivas com dados de exoma mostraram um balanço entre eventos de novo e herdados, separando em três grupos probandos sem nenhuma variação de novo, probandos somente com variações herdadas e SNVs de novo e probandos somente com variações herdadas e CNVs de novo. Em resumo, o trabalho desenvolvido nesta tese de doutorado é inovador por:

(1) Usar dados de exoma pela primeira vez para encontrar SNVs e CNVs em pacientes com TDAH e combinar dados de variações herdados com variações de novo, além de também combinar variações raras e comuns.

(2) Sugerir que o TDAH pode ter uma arquitetura diferente em diferentes crianças, e que em geral é necessário que somente um tipo de evento de novo surja, para que a doença se desenvolva.

(3) Mostrar que genes relacionados a TDAH estão localizados na borda da rede criada com genes em sua vizinhança, confirmando o que já foi mostrado em outras doenças (Barabasi, Gulbahce et al. 2011).

(4) Confirmar funções biológicas anteriormente associadas a TDAH usando uma abordagem integrativa com dados públicos, de exoma, interação proteínaproteína e expressão no cérebro. 
(5) Sugerir que variações herdadas, quando não combinadas com variações de novo, tendem desenvolver mais comorbidades. Enquanto que crianças com variações de novo tendem a desenvolver menos comorbidades.

\section{Considerações finais e perspectivas futuras}

Levando em conta que nos últimos anos os estudos genéticos em TDAH têm desvendado só parte do que chamados de herdabilidade perdida. Mesmo com testes de associação que usam milhares de casos e controles, poucas variantes se aproximam da significância estatística aceitável ao se testarem as múltiplas variáveis que estão ao longo do genoma.

$\mathrm{O}$ uso de tecnologias de sequenciamento têm auxiliado nessa busca. No entanto, estudos mais abrangentes se fazem necessários para encontrar as causas da doença. A utilização de mais amostras e a análise de outras partes importantes do genoma, como regiões não-codificantes, podem trazer uma luz sobre o problema. Além disso, um maior aprimoramento deve ser feito em ferramentas para identificar variações de número de cópias em muitas amostras, pois até hoje, as técnicas utilizadas são na verdade uma adaptação para encontrar tais variantes em dados não gerados para tal fim.

Embora tenhamos confirmado algumas propriedades no interatoma de TDAH, como a localização relativa dos genes e algumas funções biológicas, somente estudos em nível celular e molecular mais aprofundados podem confirmar de fato quais processos estão sendo afetados no cérebro. Como um passo adiante, técnicas de simulação da ação de fármacos em alvos podem ser úteis para a criação de remédios que intervenham nas vias metabólicas afetadas, trazendo assim uma maior qualidade de vida para os portadores da doença. 


\section{Capítulo 8 - Bibliografia}

Abecasis, G. R., et al. (2010). "A map of human genome variation from populationscale sequencing." Nature 467(7319): 1061-1073.

Abecasis, G. R., et al. (2012). "An integrated map of genetic variation from 1,092 human genomes." Nature 491(7422): 56-65.

Akula, N., et al. (2011). "A network-based approach to prioritize results from genomewide association studies." PLoS One 6(9): e24220.

Akutagava-Martins, G. C., et al. (2014). "Glutamatergic copy number variants and their role in attention-deficit/hyperactivity disorder." Am J Med Genet B Neuropsychiatr Genet 165B(6): 502-509.

Archer, T., et al. (2011). "Epigenetics in Developmental Disorder: ADHD and Endophenotypes." J Genet Syndr Gene Ther 2(104).

Ashburner, M., et al. (2000). "Gene ontology: tool for the unification of biology. The Gene Ontology Consortium." Nat Genet 25(1): 25-29.

Awadalla, P., et al. (2010). "Direct measure of the de novo mutation rate in autism and schizophrenia cohorts." Am J Hum Genet 87(3): 316-324.

Bader, G. D., et al. (2003). "BIND: the Biomolecular Interaction Network Database." Nucleic Acids Res. 31(1): 248-250.

Banaschewski, T., et al. (2010). "Molecular genetics of attention-deficit/hyperactivity disorder: an overview." Eur Child Adolesc Psychiatry 19(3): 237-257.

Barabasi, A. L., et al. (2011). "Network medicine: a network-based approach to human disease." Nat. Rev. Genet. 12(1): 56-68.

Baranzini, S. E., et al. (2009). "Pathway and network-based analysis of genome-wide association studies in multiple sclerosis." Hum. Mol. Genet. 18(11): 2078-2090.

Benjamini, Y. and Y. Hochberg (1995). "Controlling the False Discovery Rate: A Practical and Powerful Approach to Multiple Testing." Journal of the Royal Statistical Society. Series B (Methodological) 57(1): 289-300. 
Berridge, K. C. and T. E. Robinson (1998). "What is the role of dopamine in reward: hedonic impact, reward learning, or incentive salience?" Brain Res Brain Res Rev 28(3): 309-369.

Birney, E., et al. (2007). "Identification and analysis of functional elements in $1 \%$ of the human genome by the ENCODE pilot project." Nature 447(7146): 799-816.

Brookes, K., et al. (2006). "The analysis of 51 genes in DSM-IV combined type attention deficit hyperactivity disorder: association signals in DRD4, DAT1 and 16 other genes." Mol Psychiatry 11(10): 934-953.

Brown, K. R. and I. Jurisica (2005). "Online predicted human interaction database." Bioinformatics 21(9): 2076-2082.

Bush, W. S. and J. H. Moore (2012). "Chapter 11: Genome-wide association studies." PLoS Comput Biol 8(12): e1002822.

Cai, J. J., et al. (2010). "Broker genes in human disease." Genome Biol Evol 2: 815825.

Chang, S., et al. (2012). "Prioritization of candidate genes for attention deficit hyperactivity disorder by computational analysis of multiple data sources." Protein Cell 3(7): 526-534.

Chavan, S. S., et al. (2013). "Towards the integration, annotation and association of historical microarray experiments with RNA-seq." BMC Bioinformatics 14 Suppl 14: S4.

Cingolani, P., et al. (2012). "A program for annotating and predicting the effects of single nucleotide polymorphisms, SnpEff: SNPs in the genome of Drosophila melanogaster strain w1118; iso-2; iso-3." Fly (Austin) 6(2): 80-92.

Cotsapas, C., et al. (2011). "Pervasive sharing of genetic effects in autoimmune disease." PLoS Genet 7(8): e1002254.

Crider, A., et al. (2014). "Dysregulation of estrogen receptor beta (ERbeta), aromatase (CYP19A1), and ER co-activators in the middle frontal gyrus of autism spectrum disorder subjects." Mol Autism 5(1): 46.

Croft, D., et al. (2014). "The Reactome pathway knowledgebase." Nucleic Acids Res 42(Database issue): D472-477. 
Cross-Disorder Group of the Psychiatric Genomics Consortium (2013). "Identification of risk loci with shared effects on five major psychiatric disorders: a genome-wide analysis." Lancet 381(9875): 1371-1379.

Crow, J. F. (2000). "The origins, patterns and implications of human spontaneous mutation." Nat Rev Genet 1(1): 40-47.

de Silva, M. G., et al. (2003). "Disruption of a novel member of a sodium/hydrogen exchanger family and DOCK3 is associated with an attention deficit hyperactivity disorder-like phenotype." J Med Genet 40(10): 733-740.

dela Pena, I., et al. (2014). "Prefrontal cortical and striatal transcriptional responses to the reinforcing effect of repeated methylphenidate treatment in the spontaneously hypertensive rat, animal model of attention-deficit/hyperactivity disorder (ADHD)." Behav Brain Funct 10: 17.

DePristo, M. A., et al. (2011). "A framework for variation discovery and genotyping using next-generation DNA sequencing data." Nat Genet 43(5): 491-498.

Devlin, B. and K. Roeder (1999). "Genomic control for association studies." Biometrics 55(4): 997-1004.

Devlin, B., et al. (2001). "Genomic control, a new approach to genetic-based association studies." Theor Popul Biol 60(3): 155-166.

Devlin, B. and S. W. Scherer (2012). "Genetic architecture in autism spectrum disorder." Curr Opin Genet Dev 22(3): 229-237.

Durinck, S., et al. (2009). "Mapping identifiers for the integration of genomic datasets with the R/Bioconductor package biomaRt." Nat Protoc 4(8): 1184-1191.

Ehret, G. B., et al. (2011). "Genetic variants in novel pathways influence blood pressure and cardiovascular disease risk." Nature 478(7367): 103-109.

Elia, J., et al. (2012). "Genome-wide copy number variation study associates metabotropic glutamate receptor gene networks with attention deficit hyperactivity disorder." Nat Genet 44(1): 78-84.

ENCODE Project Consortium (2012). "An integrated encyclopedia of DNA elements in the human genome." Nature 489(7414): 57-74.

Erdmann, F., et al. (2015). "Neuronal expression of the human neuropeptide $S$ receptor NPSR1 identifies NPS-induced calcium signaling pathways." PLoS One 10(2): e0117319. 
Escudero, I. and M. Johnstone (2014). "Genetics of schizophrenia." Curr Psychiatry Rep 16(11): 502.

Exome Aggregation Consortium (2015). "ExAC database." Retrieved Feb 2, 2015, 2015, from http://exac.broadinstitute.org.

Eyre-Walker, A. and P. D. Keightley (2007). "The distribution of fitness effects of new mutations." Nat Rev Genet 8(8): 610-618.

Faraone, S. V., et al. (2005). "Molecular genetics of attention-deficit/hyperactivity disorder." Biol Psychiatry 57(11): 1313-1323.

Focking, M., et al. (2015). "Proteomic and genomic evidence implicates the postsynaptic density in schizophrenia." Mol Psychiatry 20(4): 424-432.

Frazer, K. A., et al. (2009). "Human genetic variation and its contribution to complex traits." Nat. Rev. Genet. 10(4): 241-251.

Fridley, B. L. and J. M. Biernacka (2011). "Gene set analysis of SNP data: benefits, challenges, and future directions." Eur J Hum Genet 19(8): 837-843.

Fromer, M., et al. (2014). "De novo mutations in schizophrenia implicate synaptic networks." Nature 506(7487): 179-184.

Fromer, M. and S. M. Purcell (2014). "Using XHMM Software to Detect Copy Number Variation in Whole-Exome Sequencing Data." Curr Protoc Hum Genet 81: 723 21-27 2321.

Ghani, M., et al. (2013). "Evidence of recessive Alzheimer disease loci in a Caribbean Hispanic data set: genome-wide survey of runs of homozygosity." JAMA Neurol 70(10): 1261-1267.

Girirajan, S., et al. (2011). "Relative burden of large CNVs on a range of neurodevelopmental phenotypes." PLoS Genet 7(11): e1002334.

Girirajan, S. and E. E. Eichler (2010). "Phenotypic variability and genetic susceptibility to genomic disorders." Hum Mol Genet 19(R2): R176-187.

Glessner, J. T., et al. (2014). "Increased frequency of de novo copy number variants in congenital heart disease by integrative analysis of single nucleotide polymorphism array and exome sequence data." Circ Res 115(10): 884-896. 
Goh, K. I. and I. G. Choi (2012). "Exploring the human diseasome: the human disease network." Brief Funct Genomics 11(6): 533-542.

Goh, K. I., et al. (2007). "The human disease network." Proc. Natl. Acad. Sci. U.S.A. 104(21): 8685-8690.

Golub, T. (2010). "Counterpoint: Data first." Nature 464(7289): 679.

Gomez-Cabrero, D., et al. (2014). "Data integration in the era of omics: current and future challenges." BMC Syst Biol 8 Suppl 2: 11.

Gordon, D., et al. (2003). "Errors and linkage disequilibrium interact multiplicatively when computing sample sizes for genetic case-control association studies." Pac Symp Biocomput: 490-501.

GTEx Consortium (2015). "Human genomics. The Genotype-Tissue Expression (GTEx) pilot analysis: multitissue gene regulation in humans." Science 348(6235): 648-660.

Guipponi, M., et al. (2014). "Exome sequencing in 53 sporadic cases of schizophrenia identifies 18 putative candidate genes." PLoS One 9(11): e112745.

Hamshere, M. L., et al. (2013). "High Loading of Polygenic Risk for ADHD in Children With Comorbid Aggression." Am J Psychiatry: .

Han, K., et al. (2015). "Fragile X-like behaviors and abnormal cortical dendritic spines in cytoplasmic FMR1-interacting protein 2-mutant mice." Hum Mol Genet 24(7): 1813-1823.

Hawi, Z., et al. (2015). "The molecular genetic architecture of attention deficit hyperactivity disorder." Mol Psychiatry 20(3): 289-297.

He, X., et al. (2013). "Integrated model of de novo and inherited genetic variants yields greater power to identify risk genes." PLoS Genet 9(8): e1003671.

Hirschhorn, J. N. and M. J. Daly (2005). "Genome-wide association studies for common diseases and complex traits." Nat Rev Genet 6(2): 95-108.

Hoischen, A., et al. (2010). "De novo mutations of SETBP1 cause Schinzel-Giedion syndrome." Nat Genet 42(6): 483-485.

Hoischen, A., et al. (2011). "De novo nonsense mutations in ASXL1 cause BohringOpitz syndrome." Nat Genet 43(8): 729-731. 
Holmes, J., et al. (2000). "A family-based and case-control association study of the dopamine D4 receptor gene and dopamine transporter gene in attention deficit hyperactivity disorder." Mol Psychiatry 5(5): 523-530.

Hu, Y. J., et al. (2015). "Integrative analysis of sequencing and array genotype data for discovering disease associations with rare mutations." Proc Natl Acad Sci U S A 112(4): 1019-1024.

Ideker, T. and R. Sharan (2008). "Protein networks in disease." Genome Res 18(4): 644-652.

Imamura, M. and S. Maeda (2011). "Genetics of type 2 diabetes: the GWAS era and future perspectives [Review]." Endocr J 58(9): 723-739.

International HapMap 3 Consortium, et al. (2010). "Integrating common and rare genetic variation in diverse human populations." Nature 467(7311): 52-58.

Jia, P. and Z. Zhao (2012). "Searching joint association signals in CATIE schizophrenia genome-wide association studies through a refined integrative network approach." BMC Genomics 13 Suppl 6: S15.

Kanehisa, M. and S. Goto (2000). "KEGG: kyoto encyclopedia of genes and genomes." Nucleic Acids Res 28(1): 27-30.

Kavanagh, D. H., et al. (2014). "Schizophrenia genetics: emerging themes for a complex disorder." Mol Psychiatry.

Kerem, B., et al. (1989). "Identification of the cystic fibrosis gene: genetic analysis." Science 245(4922): 1073-1080.

Kerner, B. (2014). "Genetics of bipolar disorder." Appl Clin Genet 7: 33-42.

Kerrien, S., et al. (2012). "The IntAct molecular interaction database in 2012." Nucleic Acids Res 40(Database issue): D841-846.

Keshava Prasad, T. S., et al. (2009). "Human Protein Reference Database-2009 update." Nucleic Acids Res 37(Database issue): D767-772.

Krumm, N., et al. (2013). "Transmission disequilibrium of small CNVs in simplex autism." Am J Hum Genet 93(4): 595-606.

Lander, E. S., et al. (2001). "Initial sequencing and analysis of the human genome." Nature 409(6822): 860-921. 
Lantieri, F., et al. (2010). "Analysis of GWAS top hits in ADHD suggests association to two polymorphisms located in genes expressed in the cerebellum." Am J Med Genet B Neuropsychiatr Genet 153B(6): 1127-1133.

Lasky-Su, J., et al. (2008). "Genome-wide association scan of the time to onset of attention deficit hyperactivity disorder." Am J Med Genet B Neuropsychiatr Genet 147B(8): 1355-1358.

Lasky-Su, J., et al. (2008). "Genome-wide association scan of quantitative traits for attention deficit hyperactivity disorder identifies novel associations and confirms candidate gene associations." Am J Med Genet B Neuropsychiatr Genet 147B(8): $1345-1354$.

Lee, S. H., et al. (2013). "Genetic relationship between five psychiatric disorders estimated from genome-wide SNPs." Nat Genet 45(9): 984-994.

Lee, T. L., et al. (2012). "Integrative gene network analysis provides novel regulatory relationships, genetic contributions and susceptible targets in autism spectrum disorders." Gene 496(2): 88-96.

Lesch, K. P., et al. (2011). "Genome-wide copy number variation analysis in attention-deficit/hyperactivity disorder: association with neuropeptide $\mathrm{Y}$ gene dosage in an extended pedigree." Mol Psychiatry 16(5): 491-503.

Lesch, K. P., et al. (2008). "Molecular genetics of adult ADHD: converging evidence from genome-wide association and extended pedigree linkage studies." J Neural Transm 115(11): 1573-1585.

Li, H. and R. Durbin (2009). "Fast and accurate short read alignment with BurrowsWheeler transform." Bioinformatics 25(14): 1754-1760.

Li, W., et al. (2015). "Genetic association of ACSM1 variation with schizophrenia and major depressive disorder in the Han Chinese population." Am J Med Genet B Neuropsychiatr Genet 168(2): 144-149.

Licata, L., et al. (2012). "MINT, the molecular interaction database: 2012 update." Nucleic Acids Res 40(Database issue): D857-861.

Lionel, A. C., et al. (2011). "Rare copy number variation discovery and cross-disorder comparisons identify risk genes for ADHD." Sci Transl Med 3(95): 95ra75.

Liu, L., et al. (2013). "Robust methods for population stratification in genome wide association studies." BMC Bioinformatics 14: 132. 
Lonsdale, J., et al. (2013). "The Genotype-Tissue Expression (GTEx) project." Nat Genet 45(6): 580--585.

Maciejewski, H. (2014). "Gene set analysis methods: statistical models and methodological differences." Brief Bioinform 15(4): 504-518.

Manichaikul, A., et al. (2010). "Robust relationship inference in genome-wide association studies." Bioinformatics 26(22): 2867-2873.

Manolio, T. A., et al. (2009). "Finding the missing heritability of complex diseases." Nature 461(7265): 747-753.

Martin, J., et al. (2015). "The relative contribution of common and rare genetic variants to ADHD." TransI Psychiatry 5: e506.

Mathew, C. G. (2008). "New links to the pathogenesis of Crohn disease provided by genome-wide association scans." Nat Rev Genet 9(1): 9-14.

Mayo, O. (2007). "The rise and fall of the common disease-common variant (CD-CV) hypothesis: how the sickle cell disease paradigm led us all astray (or did it?)." Twin Res Hum Genet 10(6): 793-804.

McClellan, J. M., et al. (2007). "Schizophrenia: a common disease caused by multiple rare alleles." Br J Psychiatry 190: 194-199.

McLysaght, A., et al. (2014). "Ohnologs are overrepresented in pathogenic copy number mutations." Proc Natl Acad Sci U S A 111(1): 361-366.

Michael Lawrence, R. G., Vincent Carey (2009). "rtracklayer: an R package for interfacing with genome browsers." Bioinformatics 25(14): 1841-1842.

Mitchell, K. J. (2012). "What is complex about complex disorders?" Genome Biol 13(1): 237.

Mitchell, K. J. and D. J. Porteous (2011). "Rethinking the genetic architecture of schizophrenia." Psychol Med 41(1): 19-32.

Mootha, V. K., et al. (2003). "PGC-1alpha-responsive genes involved in oxidative phosphorylation are coordinately downregulated in human diabetes." Nat Genet 34(3): 267-273.

Neale, B. M., et al. (2012). "Patterns and rates of exonic de novo mutations in autism spectrum disorders." Nature 485(7397): 242-245. 
Neale, B. M., et al. (2008). "Genome-wide association scan of attention deficit hyperactivity disorder." Am J Med Genet B Neuropsychiatr Genet 147B(8): 13371344.

Neale, B. M., et al. (2010). "Meta-analysis of genome-wide association studies of attention-deficit/hyperactivity disorder." J Am Acad Child Adolesc Psychiatry 49(9): 884-897.

Neufang, S., et al. (2015). "Modulation of prefrontal functioning in attention systems by NPSR1 gene variation." Neuroimage.

$\mathrm{Ng}$, S. B., et al. (2010). "Exome sequencing identifies MLL2 mutations as a cause of Kabuki syndrome." Nat Genet 42(9): 790-793.

Noble, W. S. (2009). "How does multiple testing correction work?" Nat Biotechnol 27(12): 1135-1137.

O'Connell, J. and J. Marchini (2012). "Joint genotype calling with array and sequence data." Genet Epidemiol 36(6): 527-537.

Ogdie, M. N., et al. (2004). "Attention deficit hyperactivity disorder: fine mapping supports linkage to 5p13, 6q12, 16p13, and 17p11." Am J Hum Genet 75(4): 661668.

Ohgi, Y., et al. (2015). "Glutamate Signaling in Synaptogenesis and NMDA Receptors as Potential Therapeutic Targets for Psychiatric Disorders." Curr Mol Med 15(3): 206-221.

Pagel, P., et al. (2005). "The MIPS mammalian protein-protein interaction database." Bioinformatics 21(6): 832-834.

Palmer, C. G., et al. (1999). "No evidence of linkage or linkage disequilibrium between DAT1 and attention deficit hyperactivity disorder in a large sample." Psychiatr Genet 9(3): 157-160.

Pfeiffer, R. M. and M. H. Gail (2003). "Sample size calculations for population- and family-based case-control association studies on marker genotypes." Genet Epidemiol 25(2): 136-148.

Poelmans, G., et al. (2011). "Integrated genome-wide association study findings: identification of a neurodevelopmental network for attention deficit hyperactivity disorder." Am J Psychiatry 168(4): 365-377. 
Polanczyk, G. and L. A. Rohde (2007). "Epidemiology of attentiondeficit/hyperactivity disorder across the lifespan." Curr Opin Psychiatry 20(4): 386392.

Poultney, C. S., et al. (2013). "Identification of small exonic CNV from whole-exome sequence data and application to autism spectrum disorder." Am J Hum Genet 93(4): 607-619.

Psychiatric GWAS Consortium Bipolar Disorder Working Group (2011). "Large-scale genome-wide association analysis of bipolar disorder identifies a new susceptibility locus near ODZ4." Nat Genet 43(10): 977-983.

Purcell, S. M., et al. (2009). "Common polygenic variation contributes to risk of schizophrenia and bipolar disorder." Nature 460(7256): 748-752.

Quinlan, A. R. (2014). "BEDTools: The Swiss-Army Tool for Genome Feature Analysis." Curr Protoc Bioinformatics 47: 1112 11-11 1234.

Razick, S., et al. (2008). "iReflndex: a consolidated protein interaction database with provenance." BMC Bioinformatics 9: 405.

Reich, D. E. and E. S. Lander (2001). "On the allelic spectrum of human disease." Trends Genet 17(9): 502-510.

Rietveld, M. J., et al. (2004). "Heritability of attention problems in children: longitudinal results from a study of twins, age 3 to $12 . " \mathrm{~J}$ Child Psychol Psychiatry 45(3): 577-588.

Roberts, J. L., et al. (2014). "Chromosomal microarray analysis of consecutive individuals with autism spectrum disorders or learning disability presenting for genetic services." Gene 535(1): 70-78.

Rodriguez-Murillo, L., et al. (2012). "The genetic architecture of schizophrenia: new mutations and emerging paradigms." Annu Rev Med 63: 63-80.

Rossin, E. J., et al. (2011). "Proteins encoded in genomic regions associated with immune-mediated disease physically interact and suggest underlying biology." PLoS Genet 7(1): e1001273.

Ruepp, A., et al. (2008). "CORUM: the comprehensive resource of mammalian protein complexes." Nucleic Acids Res. 36(Database issue): D646-650.

Ruepp, A., et al. (2010). "CORUM: the comprehensive resource of mammalian protein complexes-2009." Nucleic Acids Res. 38(Database issue): 497-501. 
Ruiz-Linares, A., et al. (2014). "Admixture in Latin America: geographic structure, phenotypic diversity and self-perception of ancestry based on 7,342 individuals." PLoS Genet 10(9): e1004572.

Salwinski, L., et al. (2004). "The Database of Interacting Proteins: 2004 update." Nucleic Acids Res. 32(Database issue): D449-451.

Sawcer, S., et al. (2011). "Genetic risk and a primary role for cell-mediated immune mechanisms in multiple sclerosis." Nature 476(7359): 214-219.

Scherag, A., et al. (2003). "Data adaptive interim modification of sample sizes for candidate-gene association studies." Hum Hered 56(1-3): 56-62.

Schizophrenia Psychiatric Genome-Wide Association Study (GWAS) Consortium (2011). "Genome-wide association study identifies five new schizophrenia loci." Nat Genet 43(10): 969-976.

Schizophrenia Working Group of the Psychiatric Genomics Consortium (2014). "Biological insights from 108 schizophrenia-associated genetic loci." Nature 511(7510): 421-427.

Sebat, J., et al. (2007). "Strong association of de novo copy number mutations with autism." Science 316(5823): 445-449.

Serretti, A. and C. Fabbri (2013). "Shared genetics among major psychiatric disorders." Lancet 381(9875): 1339-1341.

Sherry, S. T., et al. (2001). "dbSNP: the NCBI database of genetic variation." Nucleic Acids Res 29(1): 308-311.

Smalley, S. L., et al. (2002). "Genetic linkage of attention-deficit/hyperactivity disorder on chromosome 16p13, in a region implicated in autism." Am J Hum Genet 71(4): 959-963.

Sobreira, N. L., et al. (2010). "Whole-genome sequencing of a single proband together with linkage analysis identifies a Mendelian disease gene." PLoS Genet 6(6): e1000991.

Spencer, T. J., et al. (2013). "Functional genomics of attention-deficit/hyperactivity disorder (ADHD) risk alleles on dopamine transporter binding in ADHD and healthy control subjects." Biol Psychiatry 74(2): 84-89.

Stanford, S. C. (2014). "Psychostimulants, antidepressants and neurokinin-1 receptor antagonists ('motor disinhibitors') have overlapping, but distinct, effects on 
monoamine transmission: the involvement of L-type Ca2+ channels and implications for the treatment of ADHD." Neuropharmacology 87: 9-18.

Stark, C., et al. (2006). "BioGRID: a general repository for interaction datasets." Nucleic Acids Res. 34(Database issue): D535-539.

State, M. W. and P. Levitt (2011). "The conundrums of understanding genetic risks for autism spectrum disorders." Nat Neurosci 14(12): 1499-1506.

Stergiakouli, E., et al. (2012). "Investigating the contribution of common genetic variants to the risk and pathogenesis of ADHD." Am J Psychiatry 169(2): 186-194.

Subramanian, A., et al. (2005). "Gene set enrichment analysis: a knowledge-based approach for interpreting genome-wide expression profiles." Proc Natl Acad Sci U S A 102(43): 15545-15550.

Sun, Y. V. (2012). "Integration of biological networks and pathways with genetic association studies." Hum Genet 131(10): 1677-1686.

Szklarczyk, D., et al. (2015). "STRING v10: protein-protein interaction networks, integrated over the tree of life." Nucleic Acids Res 43(Database issue): D447-452.

Taly, A., et al. (2009). "Nicotinic receptors: allosteric transitions and therapeutic targets in the nervous system." Nat Rev Drug Discov 8(9): 733-750.

Tong, J., et al. (2015). "Identification and functional characterisation of a novel dopamine beta hydroxylase gene variant associated with attention deficit hyperactivity disorder." World J Biol Psychiatry: 1-9.

Torkamani, A., et al. (2008). "Pathway analysis of seven common diseases assessed by genome-wide association." Genomics 92(5): 265-272.

Van der Auwera, G. A., et al. (2013). "From FastQ data to high confidence variant calls: the Genome Analysis Toolkit best practices pipeline." Curr Protoc Bioinformatics 11(1110): 1110 11-11 1033.

Veltman, J. A. and H. G. Brunner (2012). "De novo mutations in human genetic disease." Nat Rev Genet 13(8): 565-575.

Venter, J. C., et al. (2001). "The sequence of the human genome." Science 291(5507): 1304-1351.

Vissers, L. E., et al. (2010). "A de novo paradigm for mental retardation." Nat Genet 42(12): 1109-1112. 
Voight, B. F., et al. (2010). "Twelve type 2 diabetes susceptibility loci identified through large-scale association analysis." Nat Genet 42(7): 579-589.

Wang, J., et al. (2013). "WEB-based GEne SeT AnaLysis Toolkit (WebGestalt): update 2013." Nucleic Acids Res. 41(Web Server issue): 77-83.

Wang, K., et al. (2007). "Pathway-based approaches for analysis of genomewide association studies." Am J Hum Genet 81(6): 1278-1283.

Wang, K., et al. (2007). "PennCNV: an integrated hidden Markov model designed for high-resolution copy number variation detection in whole-genome SNP genotyping data." Genome Res 17(11): 1665-1674.

Wang, K., et al. (2010). "ANNOVAR: functional annotation of genetic variants from high-throughput sequencing data." Nucleic Acids Res 38(16): e164.

Wang, K., et al. (2009). "Common genetic variants on 5p14.1 associate with autism spectrum disorders." Nature 459(7246): 528-533.

Wang, Z., et al. (2009). "RNA-Seq: a revolutionary tool for transcriptomics." Nat Rev Genet 10(1): 57-63.

Williams, N. M., et al. (2012). "Genome-wide analysis of copy number variants in attention deficit hyperactivity disorder: the role of rare variants and duplications at 15q13.3." Am J Psychiatry 169(2): 195-204.

Williams, N. M., et al. (2010). "Rare chromosomal deletions and duplications in attention-deficit hyperactivity disorder: a genome-wide analysis." Lancet 376(9750): 1401-1408.

Xu, B., et al. (2011). "Exome sequencing supports a de novo mutational paradigm for schizophrenia." Nat Genet 43(9): 864-868.

Yang, B., et al. (2007). "A meta-analysis of association studies between the 10repeat allele of a VNTR polymorphism in the 3'-UTR of dopamine transporter gene and attention deficit hyperactivity disorder." Am J Med Genet B Neuropsychiatr Genet 144B(4): 541-550.

Yang, L., et al. (2013). "Polygenic transmission and complex neuro developmental network for attention deficit hyperactivity disorder: genome-wide association study of both common and rare variants." Am J Med Genet B Neuropsychiatr Genet 162B(5): 419-430. 
Yu, T. W., et al. (2013). "Using whole-exome sequencing to identify inherited causes of autism." Neuron 77(2): 259-273.

Zayats, T., et al. (2015). "Genome-wide analysis of attention deficit hyperactivity disorder in norway." PLoS One 10(4): e0122501.

Zhang, L., et al. (2012). "ADHDgene: a genetic database for attention deficit hyperactivity disorder." Nucleic Acids Res 40(Database issue): D1003-1009.

Zhao, J., et al. (2011). "Ranking candidate disease genes from gene expression and protein interaction: a Katz-centrality based approach." PLoS One 6(9): e24306. 


\section{Tabelas Suplementares}

1. Todos os CNVs putativos (de novo ou herdados) encontrados em crianças brasileiras

\begin{tabular}{|r|r|r|l|l|l|l|l|}
\hline \multicolumn{1}{|c|}{ cro } & início & fim & amostra & cnv & herança & $\begin{array}{l}\text { banda } \\
\text { citogenética }\end{array}$ & genes \\
\hline 11 & 55032376 & 55038594 & NN3538 & DEL & de novo & $11 \mathrm{q} 11$ & TRIM48 \\
\hline 15 & 22708983 & 22710019 & $703 \mathrm{~F}$ & DUP & de novo & $15 \mathrm{q} 11.2$ & GOLGA8DP \\
\hline 17 & 43697712 & 44116052 & $772 \mathrm{~F}$ & DEL & de novo & $17 \mathrm{q} 21.31$ & $\begin{array}{l}\text { CRHR1|CRHR1- } \\
\text { IT1|KANSL1|MAPT } \\
\text { IMAPT-AS1|MAPT- } \\
\text { IT1|SPPL2C|STH }\end{array}$ \\
\hline 1 & 1387426 & 1431581 & $1084 \mathrm{~F}$ & DEL & paterno & $1 \mathrm{p} 36.33$ & ATAD3B|ATAD3C \\
\hline 1 & 154919893 & 154928567 & $894 \mathrm{~F}$ & DEL & paterno & $1 \mathrm{q} 21.3$ & PBXIP1 \\
\hline 1 & 155184845 & 155205102 & $894 \mathrm{~F}$ & DUP & paterno & $1 \mathrm{q} 22$ & GBA|GBAP1 \\
\hline 7 & 72418838 & 72420735 & NN2742 & DUP & paterno & $7 \mathrm{q} 11.23$ & SFTPA2 \\
\hline 10 & 81315609 & 81320163 & $772 \mathrm{~F}$ & DEL & paterno & $10 \mathrm{q} 22.3$ & TRIM48 \\
\hline 11 & 55032376 & 55038594 & $1848 \mathrm{~F}$ & DEL & paterno & $11 \mathrm{q} 11$ & CYP2D6 \\
\hline 22 & 42522502 & 42526883 & $772 \mathrm{~F}$ & DUP & paterno & $22 \mathrm{q} 13.2$ & $\begin{array}{l}\text { NSUN5P2|POM12 } \\
1\end{array}$ \\
\hline 19 & 6375713 & 6387570 & $703 \mathrm{~F}$ & DUP & materno & $19 \mathrm{p} 13.3$ & GTF2F1|PSPN \\
\hline 19 & 39225453 & 39229288 & $\mathrm{NN2901}$ & DEL & materno & $19 \mathrm{q} 13.2$ & CAPN12 \\
\hline 22 & 21828886 & 21842312 & $1350 \mathrm{~F}$ & DEL & materno & $22 \mathrm{q} 11.21$ & PI4KAP2 \\
\hline
\end{tabular}

2. Todos os SNVs heterozigóticos encontrados nas crianças brasileiras com TDAH https://www.dropbox.com/s/jkdlf9ju3mq03up/SupTable_heterozygous_SNVs.xlsx?dl= $\underline{0}$

3. Todos os SNVs homozigóticos (com variação heterozigótica nos pais) encontrados nas crianças brasileiras com TDAH

https://www.dropbox.com/s/qeidstdl3orgvj1/SupTable_homozygous_SNVs.xlsx?dl=0

4. Contagens de variantes herdadas (CNVs e SNVs combinados), SNVs de novo e CNVs de novo em crianças brasileiras com TDAH.

\begin{tabular}{|l|l|r|r|r|r|r|r|r|}
\hline & & \multicolumn{2}{|c|}{ VARIAÇÃO GENÉTICA } & \multicolumn{2}{|c|}{ Diagnóstico DAWBA } & \\
\hline Família & $\begin{array}{c}\text { Gên } \\
\text { ero }\end{array}$ & $\begin{array}{c}\text { SNVs } \\
\text { de } \\
\text { novo }\end{array}$ & $\begin{array}{c}\text { CNVs } \\
\text { de } \\
\text { novo }\end{array}$ & $\begin{array}{c}\text { total de } \\
\text { variantes } \\
\text { herdadas }\end{array}$ & $\begin{array}{c}\text { total de } \\
\text { variantes }\end{array}$ & Emocional & $\begin{array}{c}\text { Transt. de } \\
\text { oposição }\end{array}$ & Comorbidades \\
\hline NN2624 & $\mathrm{M}$ & 4 & 0 & 9 & 13 & 0 & 0 & 0 \\
\hline $1013 \mathrm{~F}$ & $\mathrm{M}$ & 2 & 0 & 4 & 6 & 0 & 0 & 1 \\
\hline NN1075 & $\mathrm{M}$ & 2 & 0 & 8 & 10 & 0 & 1 & 0 \\
\hline
\end{tabular}




\begin{tabular}{|c|c|c|c|c|c|c|c|c|}
\hline NN3538 & $M$ & 1 & 1 & 25 & 27 & 0 & 0 & 0 \\
\hline 1350F & $M$ & 1 & 0 & 6 & 7 & 0 & 0 & 0 \\
\hline $1732 \mathrm{~F}$ & $M$ & 1 & 0 & 10 & 11 & 0 & 0 & 0 \\
\hline NN2901 & $F$ & 1 & 0 & 12 & 13 & 0 & 1 & 1 \\
\hline NN3752 & $\mathrm{F}$ & 1 & 0 & 15 & 16 & 1 & 0 & 1 \\
\hline $894 \mathrm{~F}$ & $F$ & 1 & 0 & 40 & 41 & 0 & 0 & 0 \\
\hline $703 \mathrm{~F}$ & $M$ & 0 & 1 & 6 & 7 & 0 & 0 & 0 \\
\hline $772 \mathrm{~F}$ & $F$ & 0 & 1 & 4 & 5 & 1 & 0 & 1 \\
\hline Médias & & 1,27 & 0,27 & 12,63 & 14,18 & 0,18 & 0,18 & 0,36 \\
\hline $756 \mathrm{~F}$ & $M$ & 0 & 0 & 15 & 15 & 0 & 0 & 0 \\
\hline NN3528 & $M$ & 0 & 0 & 18 & 18 & 1 & 0 & 1 \\
\hline $543 F$ & $M$ & 0 & 0 & 2 & 2 & 0 & 1 & 1 \\
\hline NN2742 & $M$ & 0 & 0 & 11 & 11 & 0 & 1 & 1 \\
\hline $1273 \mathrm{~F}$ & $M$ & 0 & 0 & 7 & 7 & 1 & 0 & 1 \\
\hline $698 \mathrm{~F}$ & $M$ & 0 & 0 & 9 & 9 & 0 & 1 & 1 \\
\hline $1084 \mathrm{~F}$ & $M$ & 0 & 0 & 5 & 5 & 1 & 1 & 2 \\
\hline 1090F & $M$ & 0 & 0 & 9 & 9 & 0 & 1 & 1 \\
\hline $1848 \mathrm{~F}$ & $F$ & 0 & 0 & 12 & 12 & 0 & 0 & 0 \\
\hline Médias & & 0 & 0 & 9,77 & 9,77 & 0,33 & 0,55 & 0,88 \\
\hline
\end{tabular}

5. Informações detalhadas sobre as famílias

https://www.dropbox.com/s/g051k7lffly59za/families_info.xlsx?dl=0 


\section{Publicações e experiência adquirida}

Desde 2011, como parte do trabalho como bioinformata no A.C. Camargo Cancer Center, e no trabalho conjunto com seus orientadores, o aluno tem participou de vários artigos aceitos para publicação (lista em ordem cronológica descrescente):

(1) Salameh et al. 2015. PRUNE2 is a human prostate cancer suppressor regulated by the intronic long noncoding RNA PCA3 (PNAS)

(2) Maschietto et al. 2015. Co-expression network of neural-differentiation genes shows specific pattern in schizophrenia (BMC Medical Genomics)

(3) Coutinho-Camillo et al. 2015. Expression of apoptosis-regulating miRNAs and target mRNAs in oral squamous cell carcinoma (Cancer Genetics)

(4) Baumont et al., 2014. Innate immune response is differentially dysregulated between bipolar disease and schizophrenia (Schizophrenia research)

(5) Lima and Simões et al., 2014. Network-based disease gene prioritization by hitting time analysis (IEEE 14th International Conference on Biolnformatics and BioEngineering)

(6) DelValle et al., 2014. Transcriptional profile of fibroblasts obtained from the primary site, lymph node and bone marrow of breast cancer patients (Genetics and molecular biology)

(7) Pintar et al., 2014. Early Gene Expression Changes in Skeletal Muscle from SOD1G93A Amyotrophic Lateral Sclerosis Animal Model (Cellular and molecular neurobiology)

(8) Maia et al., 2013. microRNA portraits in human vulvar carcinoma (Cancer Prevention Research)

(9) Grosso et al., 2013. Breast cancer tissue slices as a model for evaluation of response to rapamycin (Cell and tissue research)

(10) Silva et al., 2012. Transcriptional Alterations Related to Neuropathology and Clinical Manifestation of Alzheimer's Disease (PLoS ONE)

(11) Lima et al., 2012. Computing a Predictor Set Influence Zone through a Multi-Layer Genetic Network to Explore the Role of Estrogen in Breast Cancer (Advances in Breast Cancer Research)

(12) Campos et al., 2012. Differences in transcriptional effects of 1a,25 dihydroxyvitamin D3 on fibroblasts associated to breast carcinomas and from 
paired normal breast tissues (The Journal of Steroid Biochemistry and Molecular Biology)

(13) Maschietto et al., 2012. Gene expression of peripheral blood lymphocytes may discriminate patients with schizophrenia from controls (Psychiatry Research)

(14) Trapé et al., 2012. Gene Expression Profile in Response to Doxorubicin-Rapamycin Combined Treatment of HER-2-Overexpressing Human Mammary Epithelial Cell Lines (Molecular Cancer Therapeutics)

(15) Bando et al., 2011. Hippocampal CA3 transcriptome signature correlates with initial precipitating injury in refractory mesial temporal lobe epilepsy (PLoS ONE)

(16) Lima et al., 2011. Decreased AIRE Expression and Global Thymic Hypofunction in Down Syndrome (The Journal of Immunology)

Há ainda trabalhos submetidos para publicação, que estão em fase de revisão:

(1) Glessner et al. CNV Meta-Analysis of Five Major Neurodevelopmental and Neuropsychiatric Disorders (submetido em fevereiro de 2015 à Nature Molecular Psychiatry)

(2) Cappi et al. Whole-exome sequencing in obsessive-compulsive disorder identifies rare mutations in immunological pathways (submetido em fevereiro de 2015 à Nature Translational Psychiatry)

O doutorado em Bioinformática na Universidade de São Paulo teve início em agosto de 2011, e durante esse período o seguinte foi realizado:

\section{$-2^{\circ}$ semestre de 2011}

Disciplina MAC5912-1/2 - Introdução a Redes Booleanas Probabilísticas (8 créditos. Instituto de Matemática e Estatística - Universidade de São Paulo). Resultado: aprovado com conceito B.

Disciplina MAC5917-1/1 - Introdução à Biologia de Sistemas (8 créditos. Instituto de Matemática e Estatística - Universidade de São Paulo). Resultado: aprovado com conceito $A$.

$-1^{\circ}$ semestre de 2012 
Disciplina BIB5709-3/1 - Genômica (5 créditos. Instituto de Biociências Universidade de São Paulo). Resultado: aprovado com conceito A.

Disciplina MPS5790-1/2 - Genética e Transtornos Psiquiátricos (8 créditos. Faculdade de Medicina - Universidade de São Paulo). Resultado: aprovado com conceito A.

Disciplina QBQ5773-3/1 - Introdução à Biologia de Sistemas (1 crédito. Instituto de Química - Universidade de São Paulo). A disciplina foi ministrada como um minicurso de 2 dias por Neil Clark, pesquisador do Hospital Mount Sinai, de Nova Iorque, Estados Unidos. Resultado: aprovado com conceito A.

\section{$-2^{\circ}$ semestre de 2012}

Disciplina IBI5035-1/1 - Biologia Molecular Computacional (8 créditos. Instituto de Química - Universidade de São Paulo). Resultado: aprovado com conceito A.

\section{$-1^{\circ}$ semestre de 2013}

Conclusão e análise dos experimentos com dados genéticos públicos de TDAH.

\section{- $2^{\circ}$ semestre de 2013}

Aprovação no exame de proficiência em línguas e conclusão do texto de qualificação.

\section{$-1^{\circ}$ e $2^{\circ}$ semestres de 2014}

Programa de doutorado sanduiche no exterior (PDSE - CAPES). O aluno esteve no Centro de Genômica Aplicada (Center for Applied Genomics) do Hospital Infantil da Filadélfia (Children's Hospital of Philadelphia - CHOP), Pensilvânia, Estados Unidos, fazendo um treinamento em Bioinfomática com foco em análise de exoma, análises de estudos de associação em genoma inteiro (Genome-wide association study GWAS) e análise de variação no número de cópias (Copy-number variation - CNV). Nesse período foi feita a análise dos dados de exoma e GWAS de amostras do Brasil. Além das análises do doutorado, o aluno participou de outros trabalhos, como o servidor GENS - GWAS Edge-based Network Search: a gene network-based pathway analysis tool for GWAS data (http://gens.caglab.org) e análises de CNVs em doenças Mendelianas. 
$-1^{\circ}$ semestre de 2015

Submissão do artigo, conclusão do texto da tese e defesa do doutorado. 